\title{
Environmental conditions during the Toarcian Oceanic Anoxic Event (T-OAE) in the westernmost Tethys: influence of the regional context on a global phenomenon
}

\author{
FRANCISCO J. RODRÍGUEZ-TOVAR \& MATIAS REOLID
}

\begin{abstract}
A geochemical analysis has been conducted in the Fuente de la Vidriera section of the External Subbetic (Betic Cordillera, southern Spain) in order to interpret the incidence of the Toarcian Oceanic Anoxic Event (T-OAE) in the westernmost end of the Tethys. The obtained values of detrital, redox and palaeoproductivity proxies throughout the succession show minor fluctuations, but only punctual significant changes. Detrital input is nearly constant during the studied interval, except punctually in the lower part of serpentinum Zone, characterized by an increase in both fluvial and eolian detrital transport. Associated to this local higher fluvial and eolian activity, a comparatively higher concentration of organic matter is punctually registered, as revealed by the comparatively highest total organic carbon (TOC) value (0.99 wt.\%). The remaining part of the section shows TOC values in the lower range of those registered in the Tethyan Toarcian sections $(<0.4 \mathrm{wt} . \%)$. The obtained ratios of redox-sensitive trace metals lead to the interpretation of oxic to dysoxic bottom-waters, with a singular sharp decrease in oxygenation corresponding to a short interval within the serpentinum Zone (sample FV-18) correlated to the T-OAE. The minor incidence of the T-OAE registered in this westernmost end of the Tethys, in which punctual dysoxic conditions are restricted only to a decimetre-scale interval reveals the importance of regional context and local oceanic-atmosphere dynamics on the local record of this phenomenon. - Key words: T-OAE, geochemical proxies, palaeoxygenation, palaeoproductivity, Jurassic, Betic Cordillera.
\end{abstract}

RodRíGueZ-TOVAR, F.J. \& REOLID, M. 2013. Environmental conditions during the Toarcian Oceanic Anoxic Event (T-OAE) in the westernmost Tethys: influence of the regional context on a global phenomenon. Bulletin of Geosciences 88(4), 697-712 (7 figures, 1 table). Czech Geological Survey, Prague. ISSN 1214-1119. Manuscript received December 1, 2012; accepted in revised form March 1, 2013; published online March 22, 2013; issued October 31, 2013.

Francisco J. Rodríguez-Tovar (corresponding author), Departamento de Estratigrafía y Paleontología, Universidad de Granada, Campus Fuentenueva sn, 18071 Granada, Spain; fjrtovar@ugr.es・Matias Reolid, Departamento de Geología and CEACT, Universidad de Jaén, Campus Las Lagunillas sn, 23071 Jaén, Spain

The Early Toarcian Oceanic Anoxic Event (T-OAE) is recognized as one of the most important environmental perturbations during the Mesozoic, with a dramatic impact on marine biota revealed by a significant mass extinction event (MEE) in benthic and pelagic groups (Hallam 1996, Wignall et al. 2005). The sedimentary record of the T-OAE is characterized by organic-rich sediments "black shales" associated with a distinctive negative excursion in the $\delta^{13} \mathrm{C}$ recorded in organic matter, biomarkers, marine carbonates, and fossil wood from marine and continental sections (e.g. Jenkyns \& Clayton 1997, Jenkyns et al. 2002, Cohen et al. 2004, Hesselbo et al. 2007, Suan et al. 2008, Hermoso et al. 2009a, Sabatino et al. 2009, Bodin et al. 2010, Gómez \& Arias 2010, Littler et al. 2010). In this sense, is significant and widely debated the absence of this excursion in the $\delta^{13} \mathrm{C}$ in the belemnite data (van de Schootbrugge et al. 2005, McArthur 2007, Metodiev et al. 2012).
The T-OAE has been extensively studied in the past three decades (from Jenkyns 1985, 1988 to recent). Still, questions regarding the mechanisms involved, the major environmental changes affecting biota, the global scale and the synchronism remain unresolved. There is no general consensus about the causes or triggering mechanisms of the T-OAE, including the massive enrichment of isotopically light carbon and its transfer between the different reservoirs (e.g., Hesselbo et al. 2000, Kemp et al. 2005), or the production of thermogenic methane during the concomitant intrusive eruption of the Karoo-Ferrar province (e.g., McElwain et al. 2005). Several environmental changes may have been involved in the mass extinction event, mainly affecting benthic organisms, such as generalized anoxia, the enhancement of greenhouse conditions and a warming trend, or the incidence of sea-level changes $(e . g$., Hallam 1986, 1987; Elmi 1996; McArthur et al. 2000; 


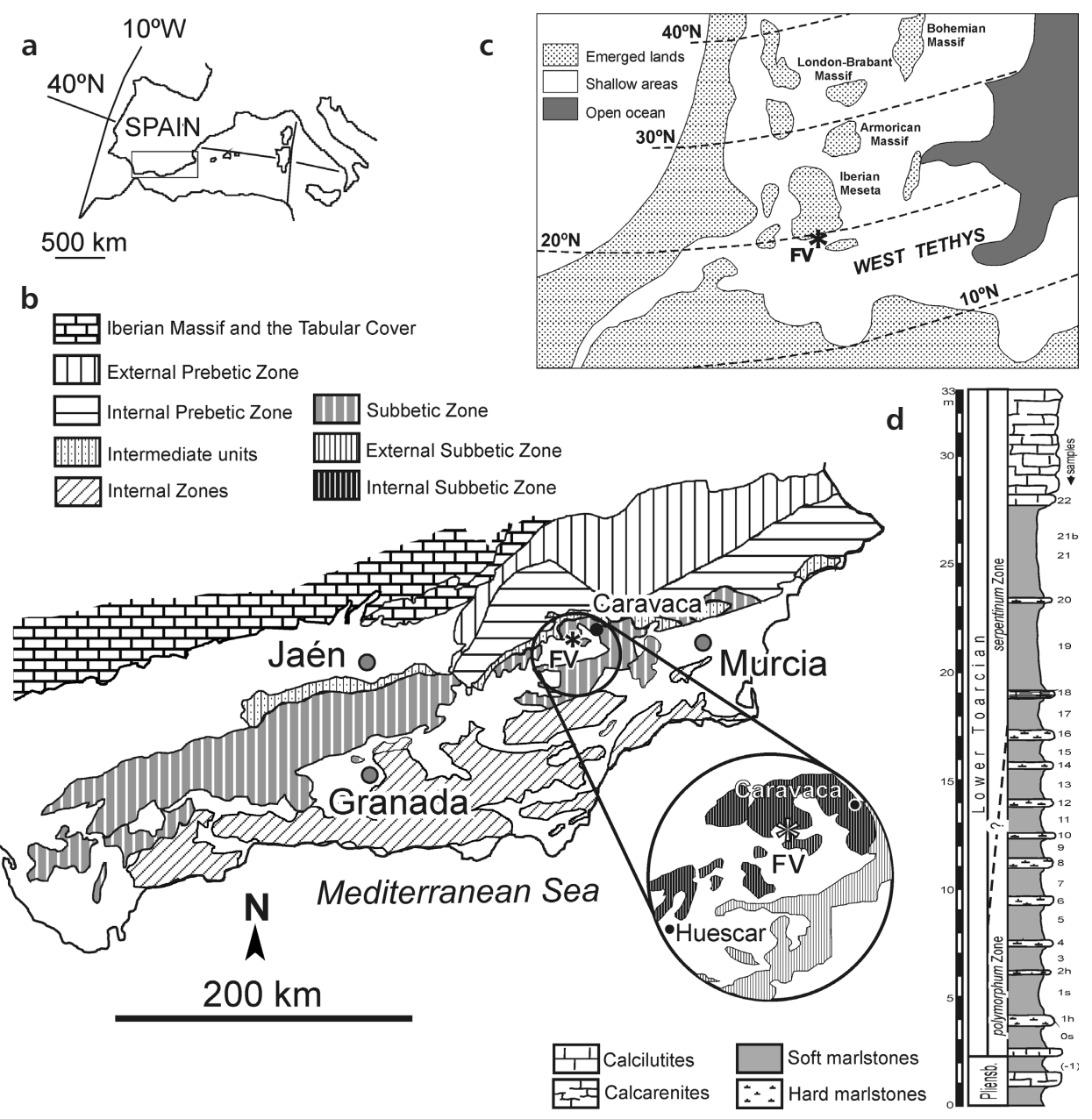

Figure 1. Geographical (a) and geological (b) location of the Fuente de la Vidriera (FV) section (start); palaeogeography (c) of the western Tethys in the Toarcian (modified after Bassoulet et al. 1993); and (d) synthetic column including studied samples.

Bailey et al. 2003; Ruban \& Tyszka 2005; Wignall et al. 2005; Ghadeer \& Macquaker 2011; Gómez \& Goy 2011; Reolid et al. 2012a; Trabucho-Alexandre et al. 2012). Originally, the T-OAE was considered as a global phenomenon based on the apparently simultaneous deposition of organic-rich facies identified in many parts around world, associated to anoxic bottom waters (Jenkyns 1988). However, recent studies point to geographical variability and the incidence of local or regional scale processes (McArthur et al. 2008, Rodríguez-Tovar \& Uchman 2010).

To improve our characterization of the T-OAE, one promising strategy is an integrative analysis, including data from biotic and abiotic components, especially in exceptional sections. This is the case of the Fuente de la Vidriera section (Betic Cordillera, southern Spain), which belongs to the westernmost Tethys and is affected by the singular ocean dynamics occurring at the Hispanic Corridor in the connection between the Western Tethys and the Proto-Atlantic seaway, at an approximate palaeolatitude of $20^{\circ} \mathrm{N}$ (Fig. 1; from fig. 6 in Jiménez et al. 1996). In this paper, an analysis of elemental geochemical proxies for the Fuente de la Vidriera section is presented, with the aim to improve characterization of the environmental effects of the T-OAE in this setting, and correlate new findings with previous interpretations based on the ichnological research (Rodríguez-Tovar \& Uchman 2010).

\section{Geological setting}

The study was carried out at the Fuente de la Vidriera (FV) section, located on a valley slope (N 38 03'19.8”; E $02^{\circ}$ $\left.07^{\prime} 01.7^{\prime \prime} ; \pm 9 \mathrm{~m}\right), 15 \mathrm{~km}$ west of the village of Barranda (Murcia Province), near Caravaca de la Cruz (Fig. 1). The study section pertains to the Upper Pliensbachian to uppermost Toarcian of the Zegrí Formation, and contains alternating marls and marly limestones in the lower part with nodular marly limestones in the upper part (J. Rey, unpublished PhD thesis, Univ. Granada, 1993, Rey \& Delgado 2002). The FV section belongs to the eastern External Subbetic (Betic Cordillera, southern Spain). In the Betic Cordillera, the External Zones comprise the Prebetic and Subbetic, consisting of thick successions of Triassic to Miocene strata (García-Hernández et al. 1980, Vera 2004 
and references therein). The Jurassic and Cretaceous deposits of the Prebetic are shallow marine, coastal plain, and continental. During the Toarcian the Subbetic was a pelagic distal setting, featuring two strings of swells with low subsidence (External and Internal Subbetic, respectively), located north and south of a more rapidly subsiding central trough called the Median Subbetic. Jurassic sedimentation in the External Subbetic is characterized by shallow shelf deposits of the lowermost Jurassic, overlain by hemipelagic facies of marls and marly limestones dating Pliensbachian-Aalenian, along with pelagic cherty limestones and nodular limestones of Middle-Late Jurassic age. In the Subbetic region overall, the External Subbetic represents swell areas produced by fragmentation of large carbonate platforms during the middle Early Jurassic (GarcíaHernández et al. 1989).

The studied Lower Toarcian section contains an approximately 30-m-thick succession of alternating soft and hard marlstones, from a calcilutite bed containing Dactylioceras (Eodactylioceras) polymorphum (Fucini) to a succession of limestone beds just below the Hildoceras bifrons Biozone of the Middle Toarcian. Biostratigraphic zonation within the Lower Toarcian of the FV section was mainly obtained based on stratigraphic correlation, due to the scarcity of index fossils (A.P. Jiménez, unpublished PhD thesis, Univ. Granada, 1986, Jiménez \& Rivas 2007). Thus, at the FV section the Dactylioceras polymorphum (approx. correlated with the Dactylioceras tenuicostatum, or Dactylioceras semicelatum Biozone) and Harpoceras serpentinum (approx. correlated with the Harpoceras serpentinus, or Harpoceras falciferum Biozone) biozones could be distinguished, although their boundaries are imprecise (A.P. Jiménez, unpublished $\mathrm{PhD}$ thesis, Univ. Granada, 1986, Jiménez et al. 1996, see Rodríguez-Tovar \& Uchman 2010, for a detailed review of the Lower Toarcian subdivisions and correlations).

\section{Materials and methods}

Bed-by-bed geochemical analysis was conducted in the alternating soft and hard marlstones with 30-m thickness. A total of 24 sampling levels were selected for a geochemical analysis and a preliminary mineralogical study. For a precise correlation of the samples here obtained with those from the previous trace fossil analysis (Rodríguez-Tovar \& Uchman 2010) we have used the same numbering.

Mineral grains were analysed under stereoscopic microscope on sieved samples, the rinsing procedure involving a column of standard stainless steel sieves with mesh openings of 250,125 , and $65 \mu \mathrm{m}$, and a gentle jet of water from the top. Residues were oven-dried at $40{ }^{\circ} \mathrm{C}$.

Elemental geochemistry analysis provides results for major (Al, K, Fe, Mg, Mn, P, Si, and Ti) and trace elements
(Ba, Co, Cr, Cu, Mo, Ni, Pb, Rb, Sr, U, V and $\mathrm{Zr}$ ). Whole-rock analyses of major elements were carried out using X-ray fluorescence (XRF) in a Philips PW 1040/10 spectrometer. Trace elements were analysed using an inductively coupled plasma-mass spectrometer (ICP-MS Perkin Elmer Sciex-Elan 5000) at the Centro de Instrumentación Científica (CIC, Universidad de Granada). The instrumental error was $\pm 2 \%$ and $\pm 5 \%$ for elemental concentrations of $50 \mathrm{ppm}$ and 5 ppm, respectively (Bea 1996).

Total organic carbon was analysed by leaching in the laboratories of SGS Canada Inc. (Ontario). Total carbon (C) contents were measured as mg and calculated as percentages of the sample weight. Precision and accuracy of the method are approximately $0.01 \%$ and $92 \%$, respectively.

In order to compare trace-element proportions in samples with variable carbonate and clays contents, it is usual to normalize trace-element concentrations to aluminium content (Calvert \& Pedersen 1993). Such normalization enabled us to avoid any lithological effect on trace or major element concentrations, assuming that $\mathrm{Al}$ content in sediments is contributed by aluminosilicates (e.g., Calvert 1990). In the last years, diverse geochemical proxies have been applied to interpret palaeoenvironmental conditions, being specially recommended the use of an integrative multi-proxy approach to characterize depositional and ecological conditions. In our case study, geochemical proxies have been used to reconstruct the terrigenous input, and the palaeoproductivity and palaeoxygenation conditions, based on the differentiation of three main groups:

a) Together with the mineral composition of the studied succession, some element/Al ratios ( $\mathrm{Si} / \mathrm{Al}, \mathrm{K} / \mathrm{Al}, \mathrm{Rb} / \mathrm{Al}$, $\mathrm{Ti} / \mathrm{Al}$, and $\mathrm{Zr} / \mathrm{Al}$ ), have been used as proxies for the reconstruction of detrital input, with the differentiation between fluvial contribution (K/Al and Rb/Al, Chester et al. 1977), and eolian transport (Zr/Al, Si/Al and Ti/Al, Pye 1987).

b) The palaeoproductivity group includes $\mathrm{Ba} / \mathrm{Al}, \mathrm{Sr} / \mathrm{Al}$, $\mathrm{P} / \mathrm{Ti}$, and Total Organic Carbon (TOC). The most extensively used geochemical proxy for palaeoproductivity reconstructions is $\mathrm{Ba}$ enrichment in marine sediments (e.g., Dehairs et al. 1987, Bishop 1988, Dymond et al. 1992, Van Os et al. 1994, Francois et al. 1995, Paytan et al. 1996, Martínez-Ruiz et al. 2000, Turgeon \& Brumsack 2006, Gallego-Torres et al. 2007, Reolid \& Martínez-Ruiz 2012), but the $\mathrm{Ba}$ excess as a palaeoproductivity proxy must be applied with caution because the Ba concentrations can be significantly modified by secondary processes. Others geochemical proxies commonly used to interpret relative fluctuations in productivity are $\mathrm{P} / \mathrm{Ti}$ ratio (Latimer \& Filippelli 2001, Robertson \& Filippelli 2008, Reolid \& Martínez-Ruiz 2012, Reolid et al. 2012a, b) and Sr/Al ratio (Niebuhr 2005, Sun et al. 2008, Reolid et al. 2012a). The $\mathrm{P} / \mathrm{Ti}$ ratio reflects excessive phosphorous delivery to the sea-bottom not supported by terrigenous components. For 
Table 1. Analysed geochemical proxies (element/Al ratios) and TOC in the Fuente de la Vidriera section.

\begin{tabular}{|c|c|c|c|c|c|c|c|c|c|c|c|c|c|c|c|}
\hline \multirow{2}{*}{$\begin{array}{l}\text { Sampling } \\
\text { level }\end{array}$} & \multicolumn{5}{|c|}{ Detrital proxies } & \multicolumn{10}{|c|}{ Redox proxies } \\
\hline & $\mathrm{Rb} / \mathrm{Al}$ & $\mathrm{Zr} / \mathrm{Al}$ & $\mathrm{Si} / \mathrm{Al}$ & $\mathrm{K} / \mathrm{Al}$ & $\mathrm{Ti} / \mathrm{Al}$ & $\mathrm{V} / \mathrm{Al}$ & $\mathrm{Pb} / \mathrm{Al}$ & $\mathrm{Cu} / \mathrm{Al}$ & $\mathrm{Ni} / \mathrm{Al}$ & $\mathrm{Cr} / \mathrm{Al}$ & $\mathrm{Co} / \mathrm{Al}$ & $\mathrm{Mo} / \mathrm{Al}$ & $\mathrm{U} / \mathrm{Th}$ & $\mathrm{Fe} / \mathrm{Al}$ & $\mathrm{Mn} / \mathrm{Al}$ \\
\hline FV-21 & 12.488 & 14.725 & 2.852 & 0.349 & 0.073 & 13.459 & 2.348 & 4.649 & 6.673 & 12.466 & 2.133 & 0.153 & 0.210 & 0.611 & 0.015 \\
\hline FV -20 & 14.604 & 14.221 & 2.933 & 0.374 & 0.064 & 12.831 & 2.152 & 6.936 & 5.643 & 11.856 & 0.943 & 0.080 & 0.235 & 0.634 & 0.011 \\
\hline FV-19 & 14.880 & 13.643 & 2.922 & 0.371 & 0.064 & 12.504 & 1.587 & 4.708 & 5.476 & 11.622 & 1.452 & 0.049 & 0.225 & 0.594 & 0.009 \\
\hline FV-18 & 14.603 & 15.907 & 3.514 & 0.355 & 0.088 & 15.060 & 1.532 & 3.978 & 12.436 & 20.611 & 2.178 & 0.065 & 0.441 & 0.783 & 0.031 \\
\hline FV-17 & 14.676 & 13.393 & 2.932 & 0.370 & 0.063 & 13.027 & 1.933 & 4.787 & 6.237 & 11.904 & 1.489 & 0.062 & 0.232 & 0.611 & 0.010 \\
\hline FV-16 & 14.334 & 13.370 & 2.949 & 0.367 & 0.066 & 13.047 & 2.155 & 5.725 & 6.827 & 12.448 & 1.871 & 0.069 & 0.255 & 0.660 & 0.011 \\
\hline FV-15 & 14.052 & 13.407 & 2.798 & 0.392 & 0.063 & 13.556 & 1.798 & 5.517 & 6.040 & 11.324 & 2.324 & 0.066 & 0.238 & 0.528 & 0.006 \\
\hline FV-14 & 14.826 & 13.302 & 3.057 & 0.367 & 0.067 & 12.990 & 2.836 & 5.847 & 6.862 & 12.981 & 1.446 & 0.113 & 0.245 & 0.634 & 0.011 \\
\hline FV-13 & 14.524 & 13.189 & 2.966 & 0.388 & 0.063 & 12.407 & 1.436 & 6.751 & 5.067 & 10.528 & 1.848 & 0.044 & 0.213 & 0.568 & 0.007 \\
\hline FV-12 & 14.769 & 14.242 & 3.094 & 0.367 & 0.071 & 13.119 & 2.665 & 4.953 & 6.812 & 12.841 & 1.211 & 0.076 & 0.275 & 0.600 & 0.012 \\
\hline FV-11 & 14.066 & 13.143 & 2.935 & 0.403 & 0.063 & 12.011 & 1.958 & 4.348 & 4.793 & 10.105 & 1.039 & 0.047 & 0.222 & 0.525 & 0.006 \\
\hline FV-10 & 15.107 & 13.506 & 3.122 & 0.386 & 0.070 & 13.050 & 1.746 & 3.659 & 6.410 & 12.011 & 2.303 & 0.050 & 0.261 & 0.591 & 0.012 \\
\hline FV-9 & 15.225 & 13.014 & 2.929 & 0.409 & 0.063 & 13.349 & 1.584 & 6.647 & 5.204 & 11.531 & 1.259 & 0.058 & 0.200 & 0.576 & 0.006 \\
\hline FV-8 & 14.890 & 13.958 & 3.114 & 0.439 & 0.061 & 14.762 & 7.516 & 24.209 & 14.278 & 14.076 & 6.715 & 0.270 & 0.294 & 0.848 & 0.012 \\
\hline FV-7 & 15.345 & 13.936 & 3.104 & 0.373 & 0.063 & 13.761 & 2.375 & 14.124 & 8.469 & 14.222 & 2.018 & 0.080 & 0.284 & 0.630 & 0.014 \\
\hline FV-6 & 15.331 & 13.440 & 2.970 & 0.400 & 0.066 & 11.624 & 1.485 & 4.971 & 5.321 & 10.606 & 2.621 & 0.043 & 0.211 & 0.508 & 0.006 \\
\hline FV -5 & 14.987 & 13.921 & 2.948 & 0.396 & 0.062 & 13.092 & 1.794 & 4.940 & 5.969 & 12.122 & 1.593 & 0.044 & 0.221 & 0.554 & 0.008 \\
\hline $\mathrm{FV}-4$ & 15.137 & 13.866 & 3.099 & 0.380 & 0.074 & 12.521 & 1.763 & 4.292 & 6.313 & 13.097 & 1.597 & 0.046 & 0.269 & 0.609 & 0.011 \\
\hline FV-3 & 15.459 & 15.702 & 3.162 & 0.411 & 0.069 & 13.777 & 1.650 & 8.072 & 5.826 & 11.932 & 2.020 & 0.040 & 0.210 & 0.566 & 0.007 \\
\hline $\mathrm{FV}-2 \mathrm{~h}$ & 14.933 & 13.899 & 3.151 & 0.380 & 0.065 & 12.835 & 2.626 & 4.174 & 7.640 & 12.756 & 2.943 & 0.070 & 0.280 & 0.719 & 0.012 \\
\hline FV-1s & 14.514 & 15.255 & 3.051 & 0.400 & 0.064 & 11.890 & 2.072 & 4.027 & 5.302 & 10.618 & 1.949 & 0.051 & 0.227 & 0.537 & 0.006 \\
\hline FV-1h & 15.399 & 15.572 & 3.133 & 0.402 & 0.064 & 12.767 & 1.866 & 4.394 & 6.312 & 12.453 & 1.935 & 0.051 & 0.240 & 0.574 & 0.010 \\
\hline FV-0s & 16.415 & 16.804 & 3.260 & 0.490 & 0.069 & 12.818 & 1.943 & 5.083 & 5.696 & 11.274 & 2.324 & 0.049 & 0.199 & 0.576 & 0.006 \\
\hline FV-(-1) & 14.385 & 14.638 & 3.241 & 0.380 & 0.064 & 13.777 & 1.793 & 8.537 & 7.276 & 13.072 & 1.144 & 0.067 & 0.234 & 0.605 & 0.005 \\
\hline
\end{tabular}

this reason, an increase in the $\mathrm{P} / \mathrm{Ti}$ ratio implies higher phosphorous sedimentation to the sea-bottom from biological processes (Latimer \& Filippelli 2001, Flores et al. 2005, Sen et al. 2008). Of additional importance is the relationship of uranium with organic matter in the sediment; high values of U/Al ratio would be congruent with high values in other palaeoproductivity proxies (Nagao \& Nakashima 1992, Baturin 2002).

Total Organic Carbon content has been used as an indirect palaeoproductivity proxy (e.g., Calvert \& Fontugne, 2001, Gupta \& Kawahata, 2006, Plewa et al. 2006, Su et al. 2008), being specially informative when compared with the results obtained from the rest of selected palaeoproductivity proxies. However, enhanced TOC contents may result from low bottom-water ventilation and oxygen depletion, and are not necessarily related to high surface productivity. However, the TOC is generally proportional to surface-water productivity and constitutes a useful palaeoproductivity proxy (Tribovillard et al. 2006).

c) Diverse element/Al ratios have been extensively used as redox proxies to interpret palaeoxygenation conditions at time of sediment deposition (Wignall \& Myers
1988; Nagao \& Nakashima 1992; Calvert \& Pedersen 1993; Jones \& Manning 1994; Powell et al. 2003; Siebert et al. 2003; Jiménez-Espejo et al. 2007; Gallego-Torres et al. 2007, 2010; Yilmaz et al. 2010; Reolid et al. 2012a, b). We selected several proxies $(\mathrm{Co} / \mathrm{Al}, \mathrm{Cu} / \mathrm{Al}, \mathrm{Cr} / \mathrm{Al}, \mathrm{V} / \mathrm{Al}$, $\mathrm{Ni} / \mathrm{Al}, \mathrm{Mo} / \mathrm{Al}, \mathrm{Pb} / \mathrm{Al}, \mathrm{Mn} / \mathrm{Al}$, and $\mathrm{U} / \mathrm{Th}$ ), focusing on those, which tend to be less soluble under reducing conditions. Some redox-sensitive metals are delivered to the sediment in association with organic matter ( $\mathrm{Ni}, \mathrm{Cu}$, and $\mathrm{Zn}$ ). These redox-sensitive elements tend to co-precipitate with sulphides (mainly pyrite) and are not usually remobilized during diagenesis in the absence of post-depositional replacement of oxidizing agents (Tribovillard et al. 2006). In the case of the manganese, high concentrations indicate an oxidation front that penetrates the sediments (e.g., Martínez-Ruiz et al. 2000, 2003).

\section{Results}

Obtained results from the analysed geochemical proxies and TOC are presented in Figs 2 to 6 and Table 1. 
Table 1. continued.

\begin{tabular}{|c|c|c|c|c|c|}
\hline \multirow{2}{*}{$\begin{array}{l}\text { Sampling } \\
\text { level }\end{array}$} & \multicolumn{4}{|c|}{ Palaeoproductivity proxies } & \multirow{2}{*}{$\begin{array}{c}\text { TOC } \\
\text { (wt.\%) }\end{array}$} \\
\hline & U/Al & $\mathrm{P} / \mathrm{Ti}$ & $\mathrm{Sr} / \mathrm{Al}$ & $\mathrm{Ba} / \mathrm{Al}$ & \\
\hline FV-21 & 0.234 & 0.106 & 112.230 & 27.156 & 0.239 \\
\hline FV-20 & 0.308 & 0.124 & 157.118 & 32.326 & 0.246 \\
\hline FV-19 & 0.296 & 0.100 & 127.365 & 32.206 & 0.194 \\
\hline FV-18 & 0.552 & 0.194 & 370.607 & 38.225 & 0.987 \\
\hline FV-17 & 0.303 & 0.110 & 155.187 & 33.966 & 0.263 \\
\hline FV-16 & 0.324 & 0.124 & 175.997 & 32.832 & 0.282 \\
\hline FV-15 & 0.258 & 0.097 & 82.020 & 26.474 & 0.243 \\
\hline FV-14 & 0.323 & 0.132 & 190.476 & 42.873 & 0.346 \\
\hline FV-13 & 0.256 & 0.109 & 105.682 & 33.760 & 0.302 \\
\hline FV-12 & 0.356 & 0.133 & 262.931 & 38.453 & 0.304 \\
\hline FV-11 & 0.259 & 0.090 & 121.344 & 28.479 & 0.331 \\
\hline FV-10 & 0.308 & 0.125 & 223.690 & 34.525 & 0.247 \\
\hline FV-9 & 0.209 & 0.082 & 85.870 & 28.567 & 0.179 \\
\hline FV-8 & 0.317 & 0.117 & 288.583 & 38.897 & 0.271 \\
\hline FV-7 & 0.330 & 0.160 & 201.834 & 29.854 & 0.188 \\
\hline FV-6 & 0.255 & 0.068 & 114.114 & 30.248 & 0.237 \\
\hline FV-5 & 0.241 & 0.091 & 127.252 & 27.930 & 0.301 \\
\hline $\mathrm{FV}-4$ & 0.334 & 0.131 & 162.752 & 32.184 & 0.261 \\
\hline FV-3 & 0.246 & 0.111 & 92.848 & 27.635 & 0.267 \\
\hline $\mathrm{FV}-2 \mathrm{~h}$ & 0.310 & 0.113 & 161.417 & 27.610 & 0.386 \\
\hline $\mathrm{FV}-1 \mathrm{~s}$ & 0.250 & 0.094 & 83.371 & 26.355 & 0.367 \\
\hline $\mathrm{FV}-1 \mathrm{~h}$ & 0.280 & 0.108 & 140.059 & 26.156 & 0.313 \\
\hline FV-0s & 0.243 & 0.091 & 81.302 & 28.267 & 0.374 \\
\hline FV-(-1) & 0.248 & 0.225 & 162.360 & 31.563 & 0.307 \\
\hline
\end{tabular}

Detrital proxies. - Preliminary mineralogical analysis reveals a similar composition in any of the marlstone levels through the FV section, consisting essentially of calcite, quartz and clay minerals (illite, smectite and interstratified illite/smectite). The element/Al ratios used for the reconstruction of detrital input ( $\mathrm{Rb} / \mathrm{Al}, \mathrm{Si} / \mathrm{Al}$, and $\mathrm{K} / \mathrm{Al}$ ) show only minor changes (Fig. 2, Table 1). Conversely, the $\mathrm{Zr} / \mathrm{Al}$ and $\mathrm{Ti} / \mathrm{Al}$ ratios temporarily manifest some increases. The $\mathrm{Zr} / \mathrm{Al}$ ratios exhibit high values in the upper part of the section, around sample FV-18, though other significant increases are noted in the middle (samples FV-7 and FV-8; $\mathrm{K} / \mathrm{Al}$ ), and lower parts (samples FV-1 and FV-2; $\mathrm{Zr} / \mathrm{Al}$, $\mathrm{Ti} / \mathrm{Al})$.

Redox proxies. - The stratigraphic evolution of the analyzed ratios used as redox proxies shows some fluctuations along the succession (Figs 3 and 4, Table 1), the most significant ones being found in samples FV-8 and FV-18. In $\mathrm{FV}-8$, relatively high values are registered for $\mathrm{V} / \mathrm{Al}, \mathrm{Pb} / \mathrm{Al}$, $\mathrm{Cu} / \mathrm{Al}, \mathrm{Ni} / \mathrm{Al}, \mathrm{Co} / \mathrm{Al}$, and $\mathrm{Mo} / \mathrm{Al}$ but without changes in $\mathrm{Mn} / \mathrm{Al}$. In this level, analysis of grains from sieved samples revealed $\mathrm{Cu}$ and $\mathrm{Fe}$ sulphides including pyrite, chalcopy- rite and covellite. In FV-18, high values are recognized for $\mathrm{V} / \mathrm{Al}, \mathrm{Ni} / \mathrm{Al}, \mathrm{Cr} / \mathrm{Al}, \mathrm{Mn} / \mathrm{Al}$, and U/Th, while other redox proxies do not increase ( $\mathrm{Pb} / \mathrm{Al}, \mathrm{Cu} / \mathrm{Al}, \mathrm{Co} / \mathrm{Al}$, and $\mathrm{Mo} / \mathrm{Al})$. A maximum in $\mathrm{Mn} / \mathrm{Al}$, together with an increase in $\mathrm{Fe} / \mathrm{Al}$, are registered at this sample level (Fig. 4, Table 1). Analysis of grains from sieved samples reveals common goethite grains in sample FV-18; whereas in sample FV-19 pyrite is totally absent, and goethite grains are very common in the $>200 \mu \mathrm{m}$ fraction.

Palaeoproductivity proxies. - Stratigraphic distribution of these proxies indicates peaks with relatively high values of $\mathrm{U} / \mathrm{Al}, \mathrm{P} / \mathrm{Ti}, \mathrm{Sr} / \mathrm{Al}$, and $\mathrm{Ba} / \mathrm{Al}$ ratios, as well as a comparatively higher TOC (Figs 5, 6, Table 1). The $\mathrm{Ba} / \mathrm{Al}$ ratio shows a slightly increasing trend, with a maximum value in FV-14 and two secondary peaks at FV-8 and FV-18, while $\mathrm{U} / \mathrm{Al}, \mathrm{P} / \mathrm{Ti}, \mathrm{Sr} / \mathrm{Al}$, and TOC clearly increase in FV-18 (Fig. 5, Table 1). In the case of the $\mathrm{Sr} / \mathrm{Al}$ ratio, the trends seen for soft and hard marlstones levels differ, with values generally higher in hard marlstones than in soft marlstones (Fig. 6, Table 1). In both cases, maximum values are in FV-8 and FV-18. In the case of P/Ti, no significant differences exist between the highest values with respect to the background. Total organic carbon content manifests minor fluctuations throughout the section. Its values are lower than 0.4 wt. $\%$ (usually ranging between 0.18 wt. $\%$ in sample FV-9 and 0.39 wt.\% in sample FV-2h), with the exception of sample FV-18 (Fig. 5, Table 1), which shows an increase in TOC, nearly $1 \%$ (0.99 wt.\%).

\section{Palaeoenvironmental changes and the T-OAE event}

The selected Lower Jurassic section represent a pelagicmarine setting in the Hispanic Corridor in a passage between the Western Tethys and the Proto-Atlantic seaway (Aberhan 2001, Bailey et al. 2003), revealing of special interest to interpret the Early Toarcian Oceanic Anoxic Event at the westernmost end of the Tethys. The External Subbetic is characterized by the complex palaeogeography and relatively isolated from open oceanic influences during the Early Toarcian.

Jiménez et al. (1996) studied the stable isotopes and recorded the characteristic negative excursion on $\delta^{13} \mathrm{C}$ values located in the serpentinum Zone. Trace fossil analysis was recently conducted in the FV section (Rodríguez-Tovar \& Uchman 2010). A well-developed endobenthic multitiered community was interpreted based on the presence of a relatively abundant, diverse, and continuous trace-fossil assemblage in the section, composed by Alcyonidiopsis, Chondrites, Nereites, Palaeophycus, Planolites, Teichichnus, Thalassinoides, and Trichichnus, with only local lamination (FV-18). Oxic or slightly dysoxic bottom waters 

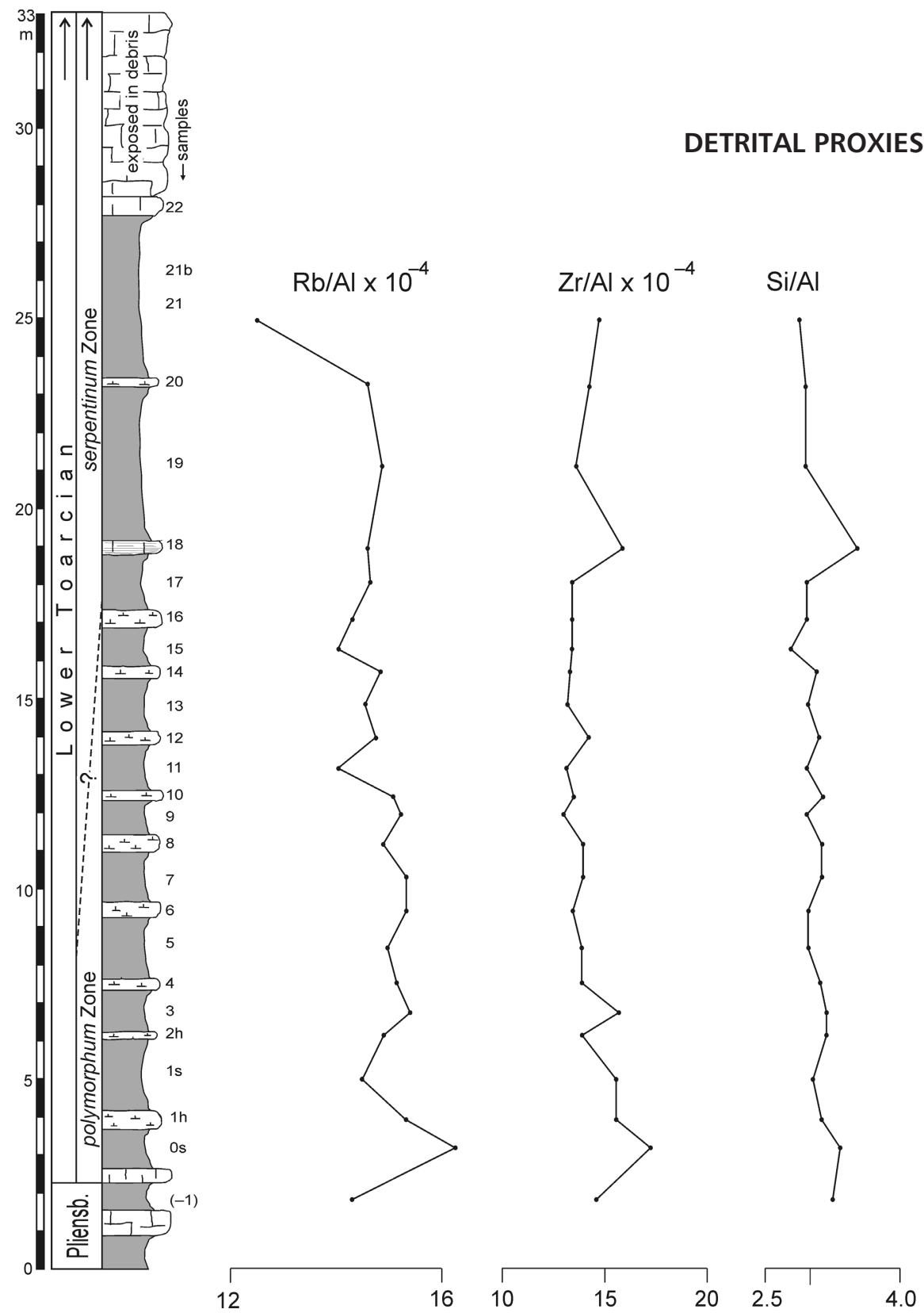

KIA

$\mathrm{Ti} / \mathrm{Al}$
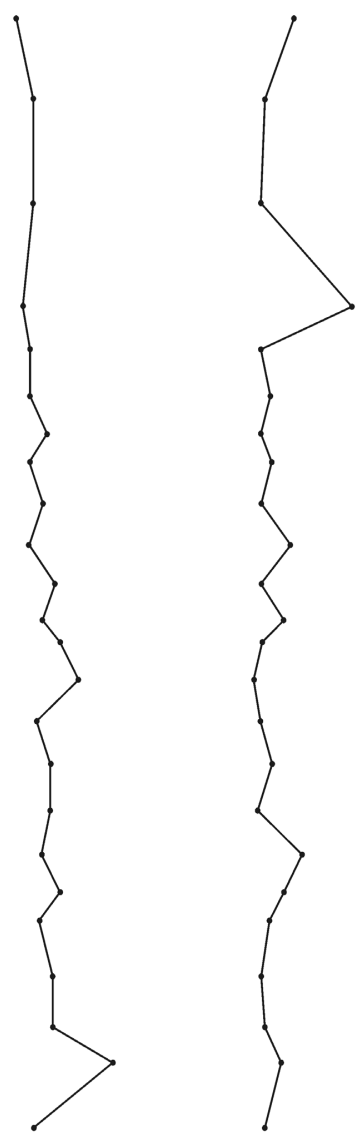

Figure 2. Stratigraphic distribution of detrital proxies throughout the Fuente de la Vidriera section.

were inferred, as well as the absence of anoxic conditions by these authors. Thus, in view of ichnological evidence, minor incidence of the T-OAE on the macro-endobenthic environment in this part of the westernmost Tethys was interpreted, and the worldwide anoxic phenomena related with the T-OAE, determining significant biotic changes, including global mass extinctions, was not recognized.

The geochemical data obtained and described here lead us to a more precise characterization of the palaeoenvironmental conditions in this area during the development of the T-OAE, and underline its particular incidence (Fig. 7).

\section{Detrital input; eolian and fluvial contributions}

Data obtained from the ratios of the detrital proxies $\mathrm{Si} / \mathrm{Al}$, $\mathrm{K} / \mathrm{Al}, \mathrm{Rb} / \mathrm{Al}, \mathrm{Ti} / \mathrm{Al}$, and $\mathrm{Zr} / \mathrm{Al}$ through the Fuente de la Vidriera section allow the interpretation of the incidence of the detrital input, and the main source of detrital material, as eolian (Zr/Al, Si/Al and Ti/Al, Pye 1987) or fluvial (K/Al and $\mathrm{Rb} / \mathrm{Al}$, Chester et al. 1977) contribution.

According to the absence of significant variations in the $\mathrm{K} / \mathrm{Al}, \mathrm{Rb} / \mathrm{Al}$, and $\mathrm{Si} / \mathrm{Al}$ ratios, a context of uniform detrital input could be inferred. This interpretation accords with the generalized homogeneous lithology through the studied 


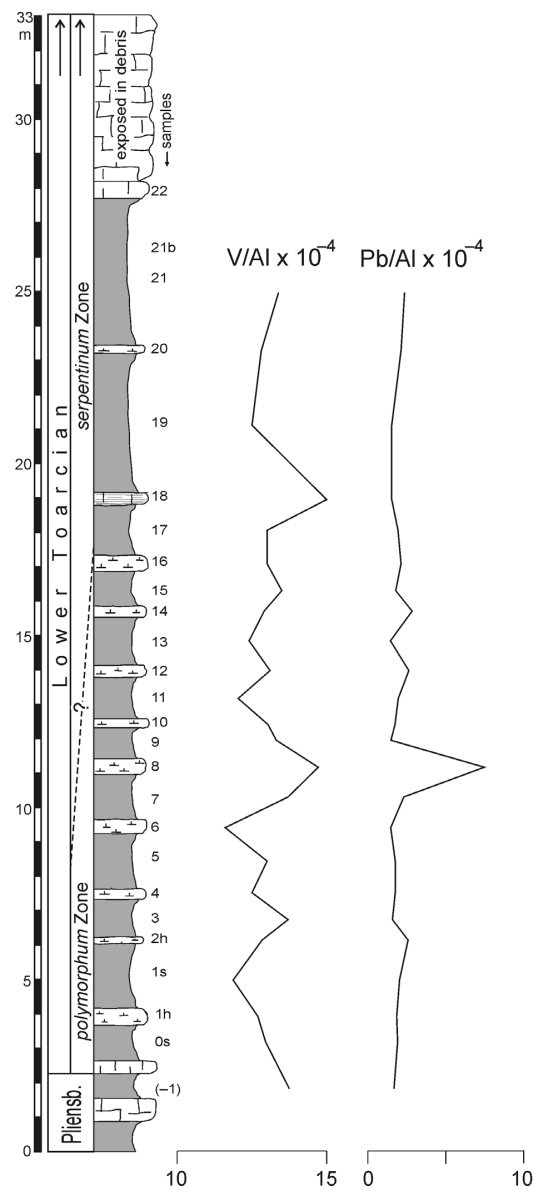

\section{REDOX PROXIES}
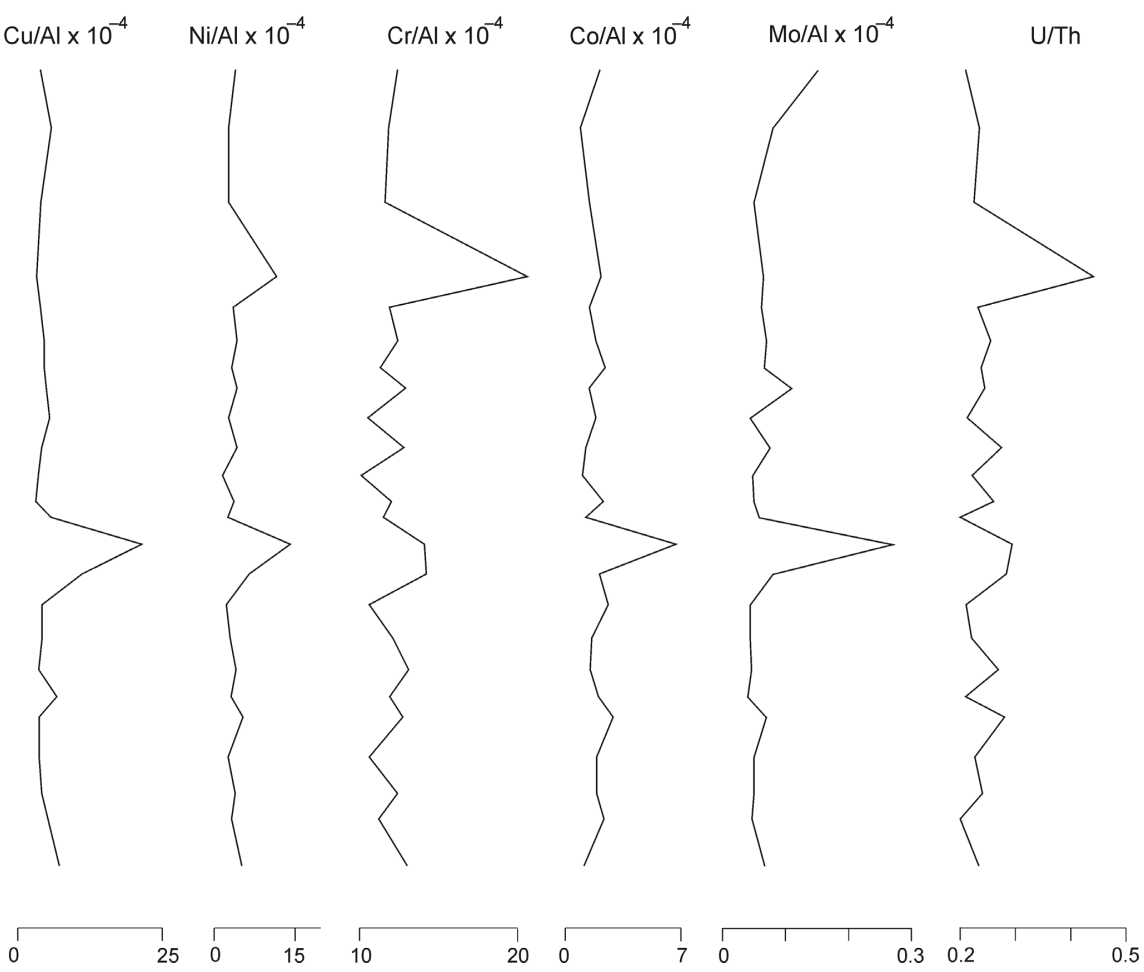

Figure 3. Stratigraphic distribution of geochemical proxies of elements which tend to be less soluble under reducing conditions, indicating redox conditions during deposition of the earliest Toarcian sediments of the Fuente de la Vidriera section.

succession, mainly consisting of the alternation of soft and hard marlstones, and the absence of significant sedimentary structures (except for bed FV-18 characterized by the presence of primary lamination). However, the punctual but simultaneous significant increases in the Ti/Al and $\mathrm{Zr} / \mathrm{Al}$ ratios registered at the upper part of the section (FV-18) may be associated to short periods of intensification in the eolian supply of siliciclastic material to the basin. This could be understood as the response to climatic changes increasing the input from the source area.

\section{Palaeoproductivity proxies and nutrient availability}

Reconstruction of nutrient availability during the studied interval has been approached based on the integrative analysis of selected palaeoproductivity proxies as $\mathrm{Ba} / \mathrm{Al}$, $\mathrm{Sr} / \mathrm{Al}, \mathrm{U} / \mathrm{Al}, \mathrm{P} / \mathrm{Ti}$, and TOC. Although the Ba excess is extensively used as a marine palaeoproductivity proxy, the Ba concentrations can be modified by secondary processes (dissolution, remobilization, etc.). In our case study, the absences of any trend in the $\mathrm{Ba} / \mathrm{Al}$ ratio from bottom to top or vice versa allow discard the alteration by diagenesis (see also Fig. 6). However, to be the most conservative as possible the $\mathrm{Ba} / \mathrm{Al}$ results will be finally integrated with those from the rest of the palaeoproductivity proxies to approach nutrient availability.

Stratigraphic fluctuations on the selected geochemical palaeoproductivy proxies reveal a similar pattern, with a generalized increase from sample $\mathrm{FV}-8$ to $\mathrm{FV}-14$ (in $\mathrm{Ba} / \mathrm{Al}$ ) and $\mathrm{FV}-18$ (in $\mathrm{Sr} / \mathrm{Al}, \mathrm{U} / \mathrm{Al}$, and $\mathrm{P} / \mathrm{Ti}$ ). This increase is not constant in the interval, but showing notable oscillations. This fluctuated increase suggests a local addition of nutrients in the middle part of the section with respect to the sediments below and above this interval, associated with intermittent processes.

The overall TOC values for the entire succession (except for sample FV-18), lower than 0.4 wt.\%, would lie in the lower range of those registered in the Tethyan Toarcian sections. In northern European sections, TOC values typically range from 5 wt.\% to 15 wt.\% (Sælen et al. 2000, Röhl et al. 2001, Bucefalo-Palliani et al. 2002, Mailliot et al. 2006, McArthur et al. 2008); in southern European sites 


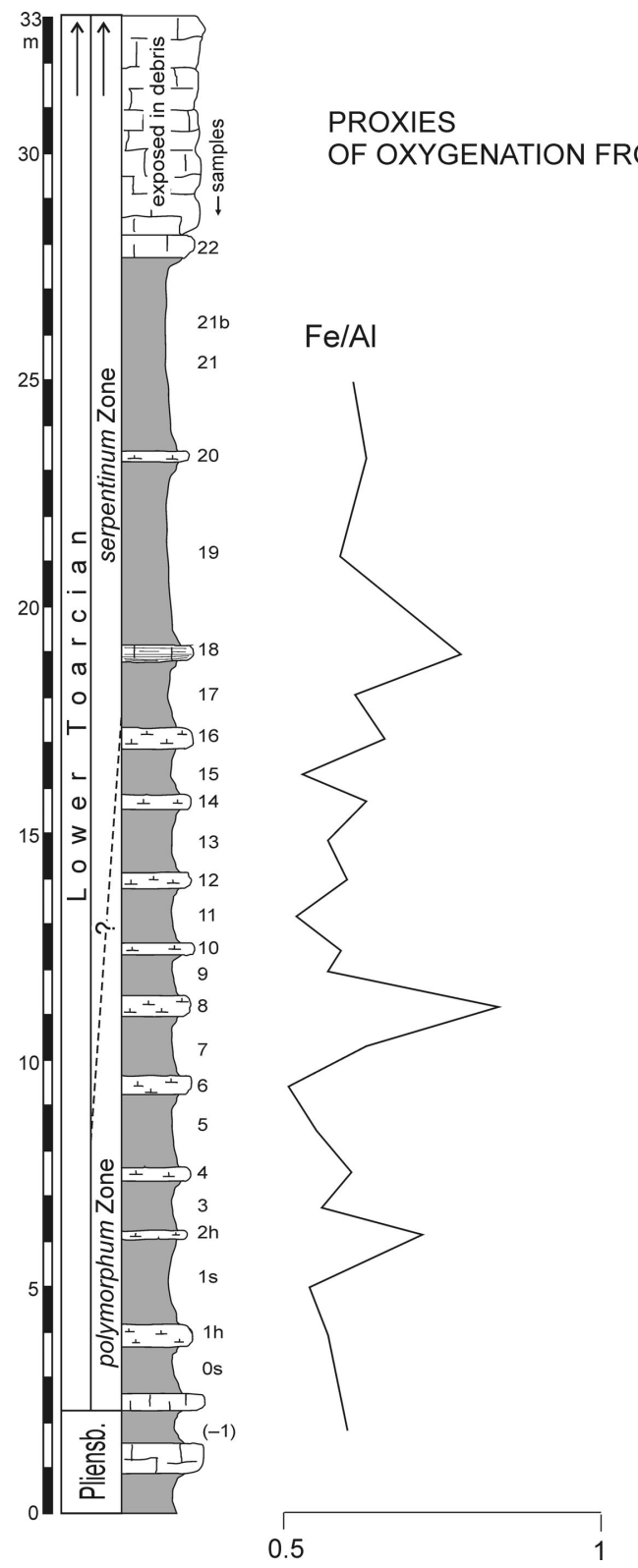

Figure 4. Stratigraphic distribution of iron (which precipitates as $\mathrm{Fe}^{3+}$ or $\mathrm{Fe}^{2+}$ depending on oxygenation) and manganese (less soluble under oxidizing conditions) represented as $\mathrm{Fe} / \mathrm{Al}$ and $\mathrm{Mn} / \mathrm{Al}$ ratios.

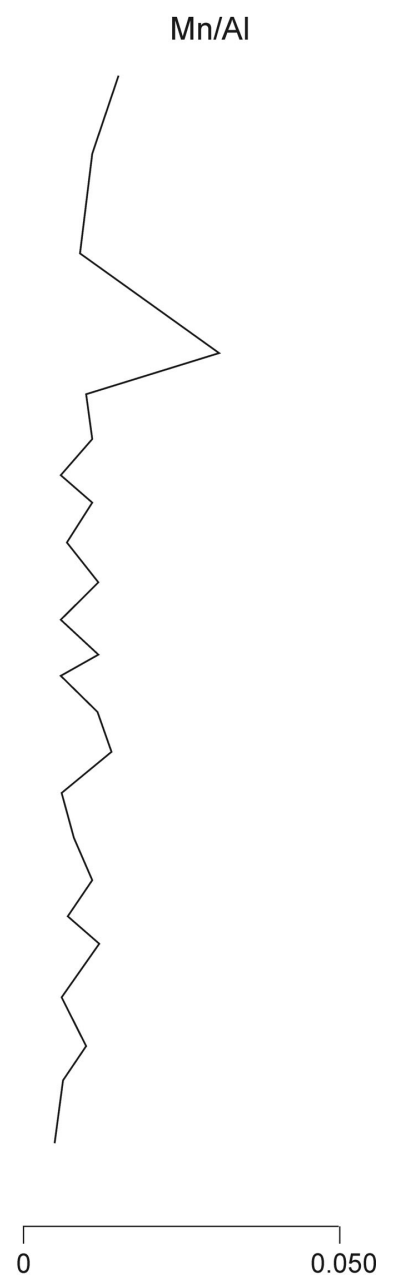

(Tethyan region) the usual values are some 0.5-3 wt.\% TOC (Jenkyns 1985, 1988; Jenkyns et al. 2002; Hesselbo et al. 2007; Bodin et al. 2010; Tyszka et al. 2010; García-Joral et al. 2011), at any rate higher than those registered in the studied succession. As McArthur et al. (2008) affirm that black shales are exceptionally rich in organic matter (5 wt.\% or more carbon content), the sediments studied here should not be considered true black shales. Yet most shales documented from southern European sites have less than $5 \mathrm{wt}$.\% TOC and are nonetheless considered to constitute black shales. Recently, black shales showing relatively low total organic carbon concentrations (TOC general values lower than 2 wt. $\%$, with data $<0.1 \mathrm{wt} . \%$ TOC), are described from several sections in Italy (Sabatino et al. 2009).
However, regardless of whether the studied succession corresponds to real black shales, what is clear is that the low overall TOC values here presented suggest lower concentrations of organic matter in the westernmost end of the Tethys than in other settings within the Tethyan Realm (see also Bodin et al. 2010, García-Joral et al. 2011, Reolid et al. 2012a). This may reflect geographical variations in the signals of the Toarcian Oceanic Anoxic Event, with a local diminution of the organic matter reaching the sea floor at the westernmost Tethys.

In this context of low overall TOC values, of special interest is the TOC maximum registered in sample FV-18, with a value $(0.99$ wt.\%) over 3 times the mean of the rest of the section (Fig. 5). Such increase in TOC underlines punctual and abrupt concentrations in organic matter with 

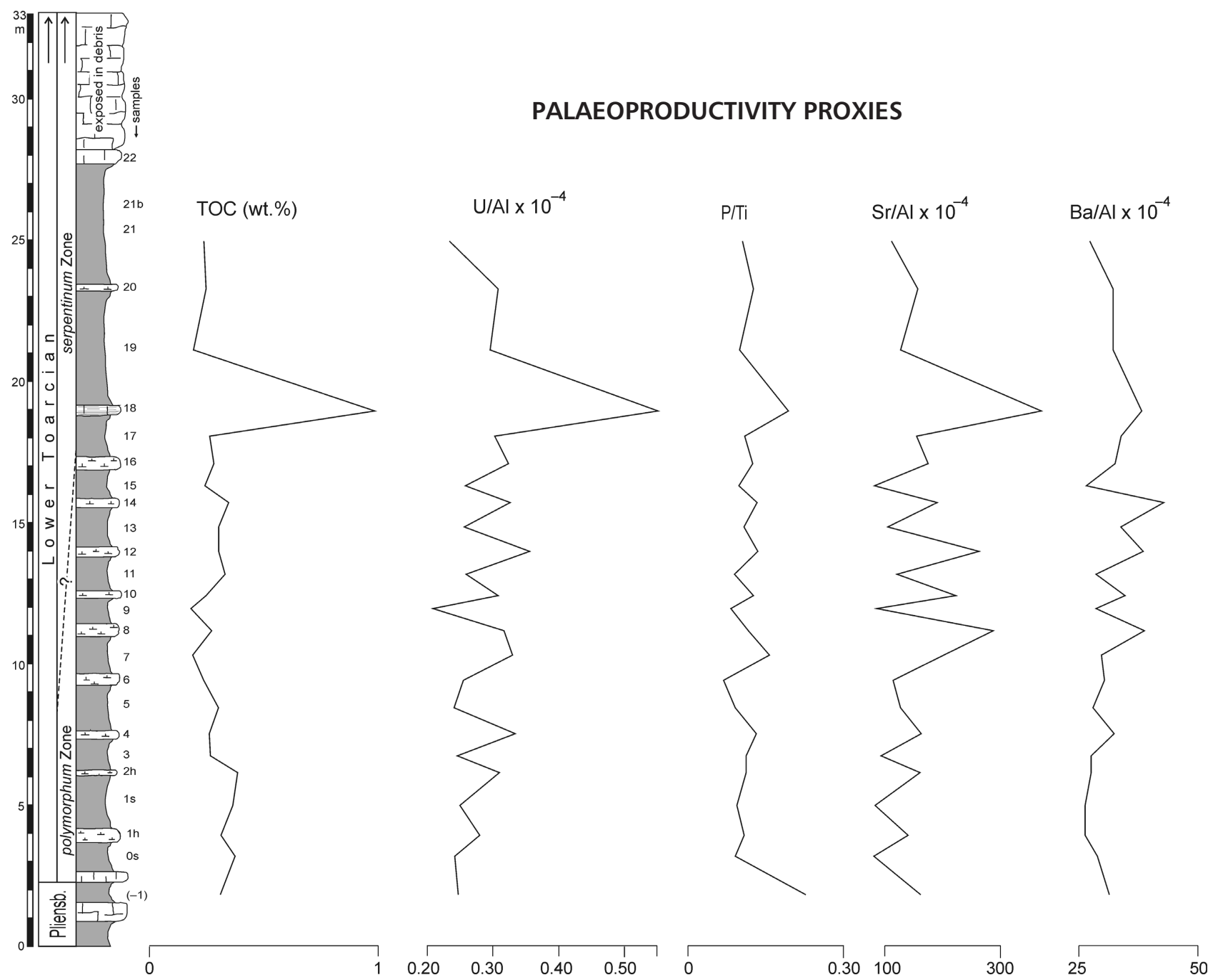

Figure 5. Stratigraphic distribution of palaeoproductivity proxies throughout the Fuente de la Vidriera section.

respect to the sediments just above and below the record, suggesting that a brief phenomenon occurred suddenly in the serpentinum Zone. Moreover, the $\mathrm{Mn} / \mathrm{Al}$ ratio indicates that the oxidation front penetrates this potentially high productivity level, consuming part of the organic matter originally present in the sediment.

\section{Palaeoxygenation conditions during the T-OAE}

As presented in Figs 3 to 5 and in Table 1, the selected ratios of redox-sensitive trace elements $(\mathrm{Co}, \mathrm{Cu}, \mathrm{Ni}, \mathrm{Cr}, \mathrm{V}$, $\mathrm{Mo}, \mathrm{Pb}, \mathrm{U}$, and $\mathrm{Th}$ ), used to interpret redox conditions in the water column and the sea-bottom, show similar patterns throughout the studied interval, with generalized low values and the absence of significant fluctuations or any observable trend. The generalized absence of high values in the ratios of the selected redox-sensitive trace metals through the studied interval suggests predominating oxic to slightly dysoxic bottom waters, discarding anoxic conditions. However, occasionally, punctual enrichments in redox sensitive elements are observed in levels FV-8 (V/Al, $\mathrm{Pb} / \mathrm{Al}, \mathrm{Cu} / \mathrm{Al}, \mathrm{Ni} / \mathrm{Al} \mathrm{Cr} / \mathrm{Al}, \mathrm{Co} / \mathrm{Al}$, and $\mathrm{Mo} / \mathrm{Al}$ ratios) and FV-18 (V/Al, Ni/Al, Cr/Al, U/Th and U/Al ratios). These local concentrations would point to decreasing oxygen conditions. U-based proxies suggest that the deposition of the bed FV-18 was in comparatively lower oxygen conditions (Figs 3 and 5).

Especially relevant is the interpretation of the $\mathrm{Fe} / \mathrm{Al}$ and $\mathrm{Mn} / \mathrm{Al}$ ratios (Fig. 4). Fe can precipitate under either reducing (as sulphides) or oxidizing conditions (as oxy-hydroxides); whereas Mn precipitates as oxy-hydroxides at the sediment-water interface when oxygen is available, and constitutes a clear mark of the oxidation front (Thomson et al. 1995, 1999; Powell et al. 2003). The enrichment of Fe in FV-8 is congruent with the dysoxic conditions indicated by other redox proxies, given that the $\mathrm{Mn} / \mathrm{Al}$ ratio is low. Analysis of grains from sieved samples allows us to ob- 


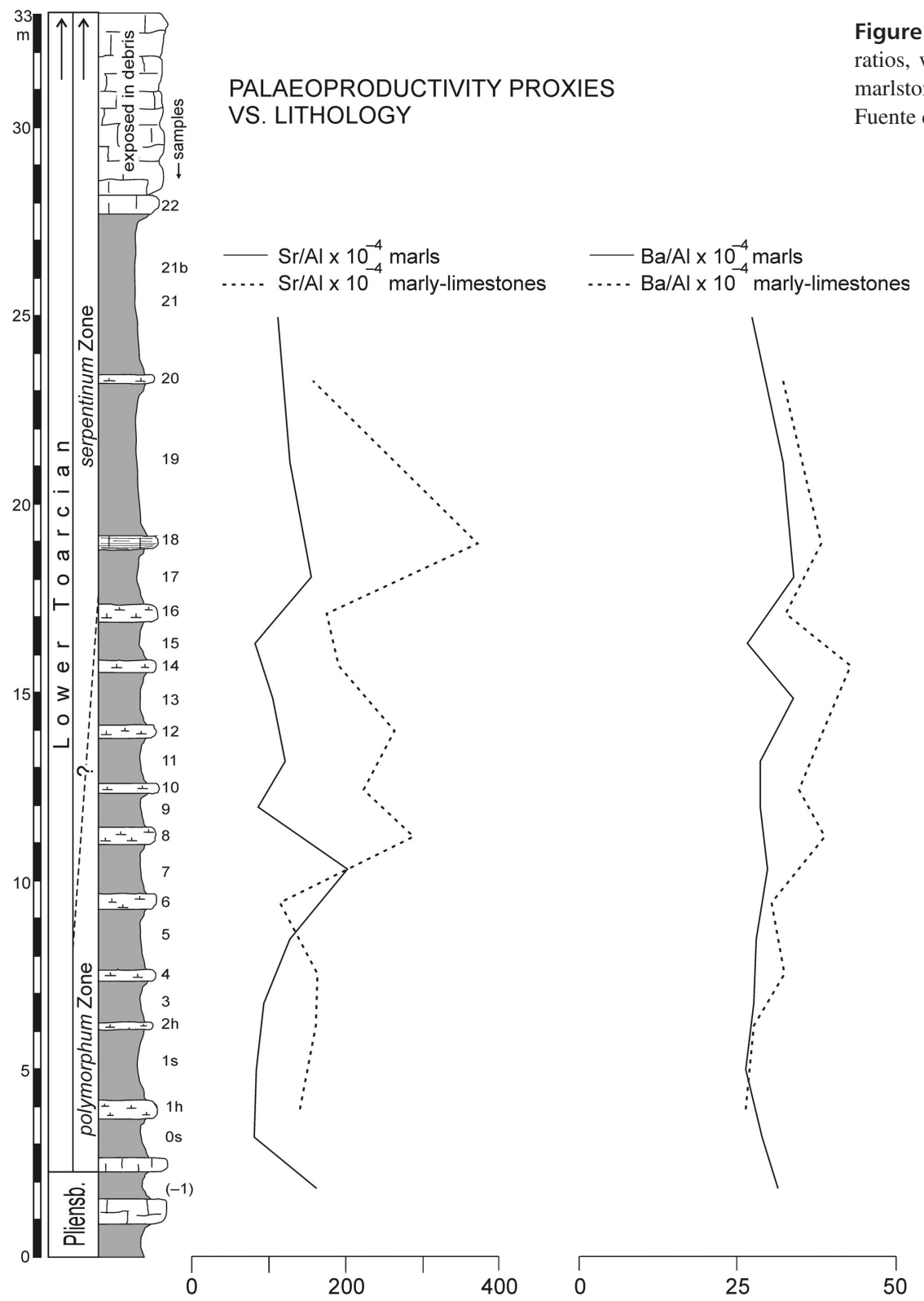

serve $\mathrm{Cu}$ and $\mathrm{Fe}$ sulphides in the form of pyrite, chalcopyrite and covellite, congruent with reducing conditions.

An abrupt return to oxic conditions below the sediment-water interface after sample FV-18 could be indicated by the high $\mathrm{Mn} / \mathrm{Al}$ ratio, which may reflect the input of well-oxygenated waters to the basin or bottom water ventilation. The oxidation front could have removed the $\mathrm{Co}, \mathrm{Cu}, \mathrm{Mo}$ and $\mathrm{Pb}$, which would explain the absence of maximum of these elements in the FV-18. The Fe/Al ratio in FV-18 is related to the presence of grains of goethite from sieved samples. The oxidation front may have consumed the organic matter originally present in the sediment (Thomson et al. 1995, 1999) meaning that TOC values would be reduced with respect to the initial sedimentary conditions.
Stratigraphic distribution of $\mathrm{Sr} / \mathrm{Al}$ and $\mathrm{Ba} / \mathrm{Al}$ with differentiation of trends in soft and in hard ente de la Vidriera section.
Hermoso et al. (2009b) described Mn enrichment in black shales from Sancerre section (Paris Basin) section interpreted as $\mathrm{Mn}^{4+}$ and $\mathrm{Mn}^{3+}$ species reduced to $\mathrm{Mn}^{2+}$ under strongly anoxic conditions, and then incorporated into carbonate lattice. This is not the case in FV section due the presence of goethite and the absence of sulphides as pyrite.

\section{Detrital input, nutrient supply and palaeoxygenation at the sea-floor and the incidence of the T-OAE}

The bulk analysis of the obtained data, together with the integration of ichnological information (Rodríguez-Tovar \& Uchman 2010), allows us to interpret the ecosedimentary 
a

\section{Dysoxic conditions}
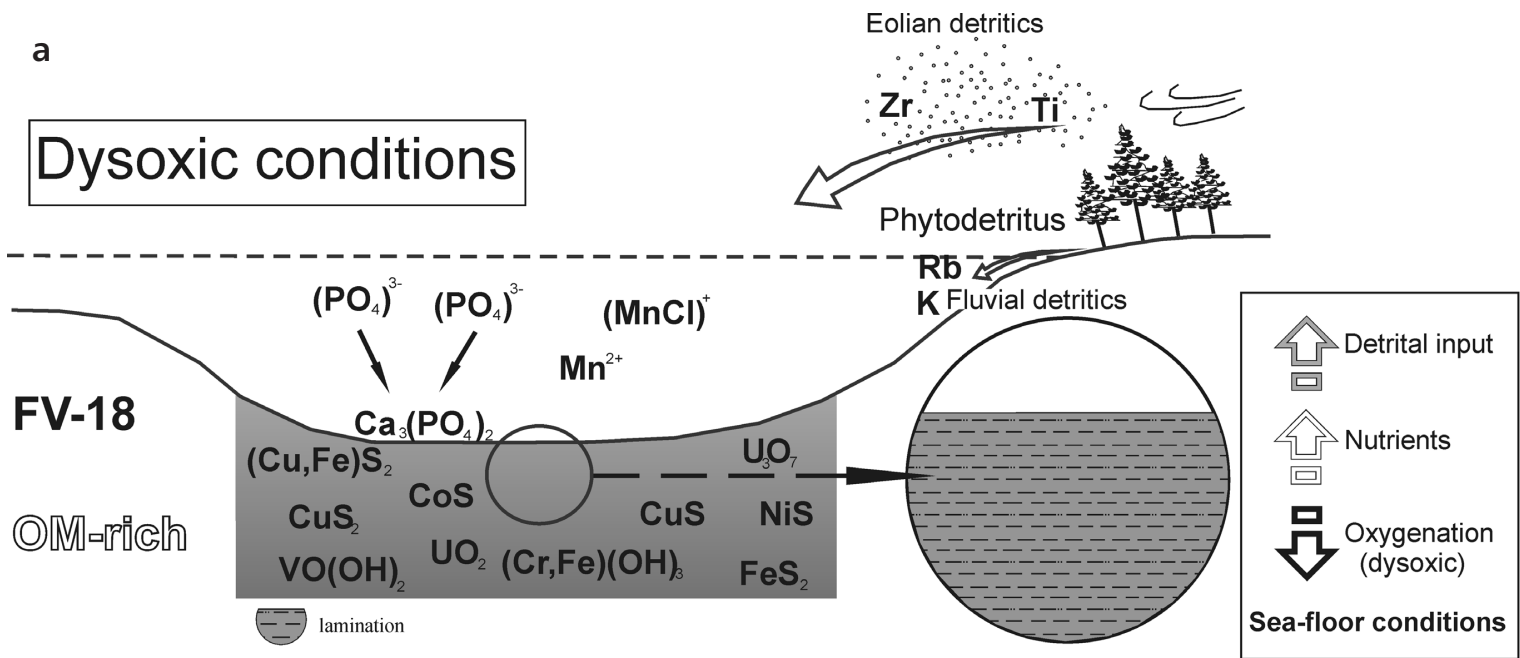

b

\section{Oxic conditions}

\section{Eolian detritics \\ $\mathrm{Zr} \cdot \mathrm{Ti}$ :}

Phytodetritus
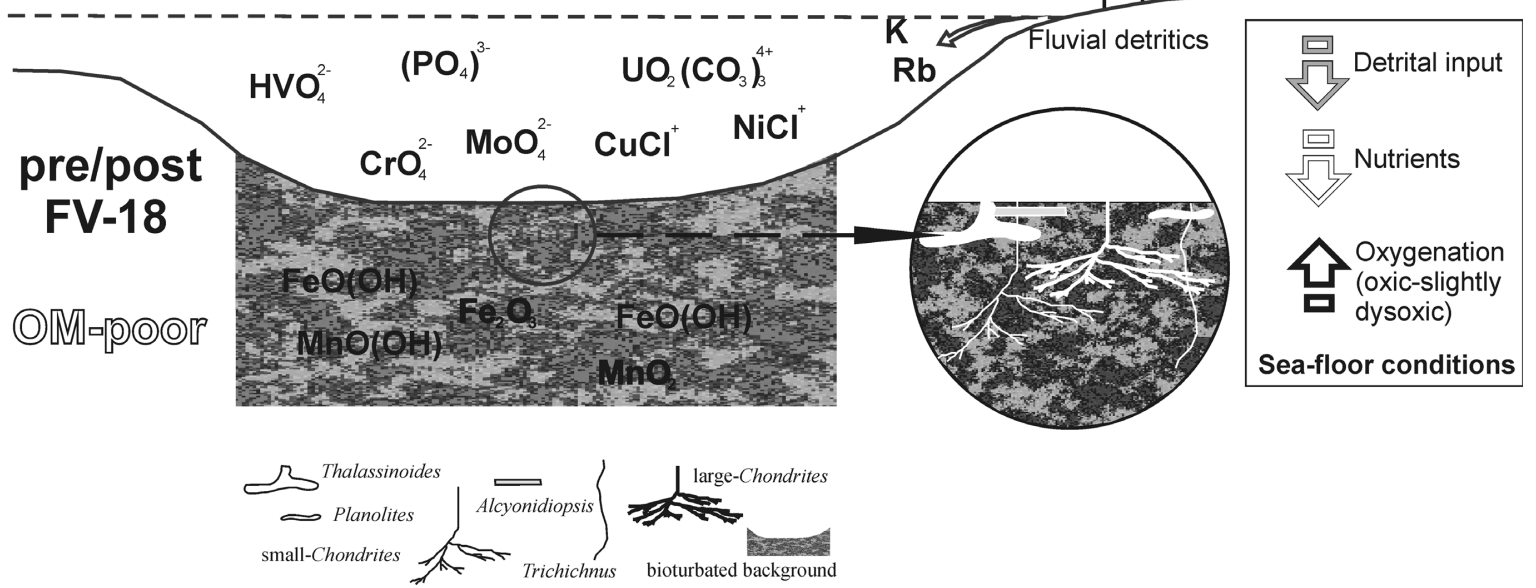

Figure 7. Palaeoenvironmental changes during deposition of FV-18 (a) and pre/post FV-18 (b) sediments, showing distribution of some trace elements studied. Note that in FV-18, under dysoxic conditions (a) trace elements sensitive to redox conditions are precipitated mainly as sulphides, the laminated sediment is organic matter-rich (OM-rich) and the detrital and phytodetritus input from emerged areas increase. In normal conditions at FV section (b), the main species in oxic seawater are in oxidation state and oxides and oxy-hydroxides of Mn and Fe precipitate in a bioturbated sediment, organic matter is scarce (OM-poor, probably oxidized) and detritals and phytodetritus are scarcer.

conditions in this westernmost end of the Tethys during the development of the T-OAE.

In a context of uniform detrital input determining a very homogeneous succession of soft and hard marlstones, minor increases in the detrital proxies reveal several short periods of accentuation in the transport of siliciclastic material to the basin. Among these, the most significant increase in fluvial and eolian detrital proxies is registered in the upper part of section FV-18. This finding can be related to a significant variation in the palaeo-depositional context, probably involving climatic changes. Associated with the higher fluvial and eolian activity, a comparatively higher concentration in organic matter is punctually registered, as derived from the comparatively higher TOC values of sample FV-18. In the rest of the succession, minor inputs of detrital material are registered in conditions of low concentration, without significant variations, in organic matter content. This generalized low concentration of organic 
matter content is associated to oxic or slightly dysoxic bottom-waters, sufficient to maintain a fairly abundant and moderately diverse endobenthic multitiered community (Rodríguez-Tovar \& Uchman 2010), as is corroborated by the absence of high concentrations of the selected redoxsensitive trace metals.

The comparatively higher concentration of organic matter registered in sample FV-18 would be associated with a sharp decrease in oxygenation, as revealed by increasing values of redox proxies, the absence of bioturbation and the presence of lamination (Rodríguez-Tovar \& Uchman 2010). In NW Europe, evidence to support marine anoxia is represented by millimetre-scale sedimentary lamination and the absence of bottom-dwelling fauna (see Hermoso et al. 2009). The highest concentrations of organic matter in the sediment associated with high values of certain element ratios support a link among TOC, palaeoxygenation conditions and the concentration of these elements. The highest values of TOC at FV-18 can be interpreted in the framework of a complex interaction of processes. Organic matter deposition was most likely related to: a) phytodetrital inputs from emerged areas correlated to increasing detrital proxies; b) an increase in marine surface productivity as indicated by high $\mathrm{Sr} / \mathrm{Al}$ and $\mathrm{P} / \mathrm{Ti}$ values; and c) oxygen depletion at the sea-bottom favouring the preservation of organic matter. The FV-8 level probably represents less accentuated oxygen depletion than in FV-18. Sample FV-18 corresponds to the lower part of the serpentinum Zone, and its geochemistry could prove useful for correlation with other sections offering the same trends in the geochemical proxies and better biostratigraphic resolution as happen in the Ratnek El Kahla section from Saharan Atlas of Algeria (Reolid et al. 2012a).

During the development of the T-OAE worldwide, in the westernmost end of the Tethys, local conditions would have assuaged the impact of this global phenomenon as reflected by the obtained geochemical data and the correlation with the ichnological information.

We cannot discard that the restricted oxygen conditions occurred in a phase of generalized transgression that involved water stratification. According to Hallam (1986, 1987) and Haq et al. (1987), among others, during the Early Toarcian a sea-level rise took place, causing maximum confinement of bottom waters of the deep sub-basins in the Western Tethys. The configuration of the Subbetic in troughs and swells, with an intricate physiography, resulted in different sub-basins, disfavouring bottom water circulation.

\section{Conclusions}

Geochemical analysis conducted in the Fuente de la Vidriera section (External Subbetic, Betic Cordillera, southern
Spain) allow us to interpret the incidence of the Toarcian Oceanic Anoxic Event (T-OAE) in the westernmost end of the Tethys. Detrital, palaeoproductivity, and redox proxies reveal a significant change in the lower part of the serpentinum Zone (bed FV-18).

Simultaneous and significant increases in the detrital proxies $\mathrm{Ti} / \mathrm{Al}$ and $\mathrm{Zr} / \mathrm{Al}$ ratios registered throughout the section - and especially in FV-18 - could be related with locally significant variations in the ocean-atmosphere dynamics due to climatic or sea-level changes affecting both fluvial and eolian processes. Increases in palaeoproductivity proxies $\mathrm{Ba} / \mathrm{Al}, \mathrm{Sr} / \mathrm{Al}$, and $\mathrm{P} / \mathrm{Ti}$ ratios, along with TOC values, mainly in sample FV-18, reveal the punctually higher addition of nutrients, and relatively high palaeoproductivity. This is followed by a generalized low concentration of organic matter content in the rest of the studied interval. According to the redox proxies, oxic to slightly dysoxic bottom waters prevail throughout the section, decreasing to dysoxic conditions in $\mathrm{FV}-18$ as revealed by the enrichment in V/Al, Ni/Al, $\mathrm{Cr} / \mathrm{Al}, \mathrm{U} / \mathrm{Th}$ and U/Al. The return to a normal oxygenation degree at sea-bottom was probably abrupt, as suggested by the high $\mathrm{Mn} / \mathrm{Al}$ ratio.

In the westernmost end of the Tethys, the local configuration of the Subbetic features troughs and swells with an intricate physiography. This resulted in a series of sub-basins where the incidence of the T-OAE was less abrupt, and there is a lack of evidence of the global anoxia inferred in many other studied successions, here represented instead by a decimetre level with dysoxic conditions.

\section{Acknowledgements}

This research was supported by Projects CGL2008-03007/CLI, CGL2012-33281, RNM-3715, RYC-2009-04316 (Ramón y Cajal Program), P11-RNM-7408, UJA2011/12/17 and the RNM-178 Group (Junta de Andalucía). M.I. Abad (Universidad de Jaén) collaborated with the clay mineral analyses.

\section{References}

Aberhan, M. 2002. Opening of the Hispanic Corridor and Early Jurassic bivalve biodiversity. Geological Society of London, Special Publications 194, 1-11.

DOI 10.1144/GSL.SP.2002.194.01.10

Al-Suwaidi, A.H., Angelozzi, G.N., Baudin, F., Damborenea, S.E., Hesselbo, S.P., Jenkyns, H.C., Manceñido, M.O. \& RicCARDI, A.C. 2010. First record of the Early Toarcian Oceanic Anoxic Event from the Southern Hemisphere, Neuquén Basin, Argentina. Journal of the Geological Society, London 167, 633-636. DOI 10.1144/0016-76492010-025

Bailey, T.R., Rosenthal, Y., McArthur, J.M., VAn DE SchootBrugge, B. \& Thirlwall, M.F. 2003. Paleoceanographic changes of the Late Pliensbachian-Early Toarcian interval: 
A possible link to the genesis of an oceanic anoxic event. Earth and Planetary Science Letters 212, 307-320. DOI 10.1016/S0012-821X(03)00278-4

Bassoulet, J.P., Elmi, S., Posson, A., Cecca, F., Bellion, Y., Guiraud, R. \& Baudin, F. 1993. Middle Toarcian (184-182 Ma), 63-80. In Dercourt, J., Ricou, L.E. \& Vrielynck, B. (eds) Atlas Tethys Paleoenvironmental Maps. Explanatory notes. Gauthiers-Villards, Paris.

BAtURIN, G.N. 2002. Uranium and phosphorous in deep-sea clay from the Pacific Ocean. Oceanology 42, 723-730.

BEA, F. 1996. Residence of REE, Y, Th and U in granites and crustal protoliths: implications for the chemistry of crustal melts. Journal of Petrology 37, 521-532.

DOI 10.1093/petrology/37.3.521

Bishop, J.K.B. 1988. The barite-opal-organic carbon association in oceanic particulate matter. Nature 332, 341-343. DOI $10.1038 / 332341 \mathrm{a} 0$

Bodin, S., Mattioli, E., Frölich, S., Marshall, J.D., Boutib, L., LAHSINI, S. \& REDFERN, J. 2010. Toarcian carbon isotope shifts and nutrient changes from the Northern margin of Gondwana (High Atlas, Morocco, Jurassic): palaeoenvironmental implications. Palaeogeography, Palaeoclimatology, Palaeoecology 297, 377-390. DOI 10.1016/j.palaeo.2010.08.018

Bucefalo-Palliani, R., Mattioli, E. \& Riding, J.B. 2002. The response of marine phytoplankton and sedimentary organic matter to the Early Toarcian (Lower Jurassic) oceanic anoxic event in northern England. Marine Micropaleontology 46, 223-245. DOI 10.1016/S0377-8398(02)00064-6

Calvert, S.E. 1990. Geochemistry and origin of the Holocene sapropel in the Black Sea, 326-352. In IтTEкKот, V., KeмPE, S., Michaelis, W. \& Spitzy, A. (eds) Facets of Modern Biogeochemistry. Springer, Berlin.

Calvert, S.E. \& Fontugne, M.R. 2001. On the late Pleistocene-Holocene sapropel record of climatic and oceanographic variability in the eastern Mediterranean. Paleoceanography 16, 78-94. DOI 10.1029/1999PA000488

Calvert, S.E. \& Pedersen, T.F. 1993. Geochemistry of recent oxic and anoxic marine sediments: Implications for the geological record. Marine Geology 113, 67-88.

DOI 10.1016/0025-3227(93)90150-T

Chester, R., Baxter, G.B., Behairy, A.K.A., Connor, K., Cross, D., Elderfield, H. \& Padgham, R.C. 1977. Soil-sized eolian dusts from the lower troposphere of the eastern Mediterranean Sea. Marine Geology 24, 201-217. DOI 10.1016/0025-3227(77)90028-7

Cohen, A.S., Coe, A.L., Harding, S.M. \& Scwark, L. 2004. Osmium isotope evidence for the regulation of atmospheric $\mathrm{CO}_{2}$ by continental weathering. Geology 32, 157-160. DOI 10.1130/G20158.1

Dehairs, F., Lambert, C.E., Chesselet, R. \& Risler, N. 1987. The biological production of marine suspended barite and the barium cycle in the western Mediterranean Sea. Biogeochemistry 4, 119-139. DOI 10.1007/BF02180151

Dymond, J., Suess, E. \& Lyle, M. 1992. Barium in deep-sea sediment: a geochemical proxy for palaeoproductivity. Paleoceanography 7, 163-181. DOI 10.1029/92PA00181

ELMI, S. 1996. Stratigraphic correlations of the main Jurassic events in the Western Mediterranean Tethys (western Algeria and eastern Morocco). Georesearch Forum 1-2, 343-357.
Flores, J.A., Sierro, F.J., Filippelli, G.M., Barcena, M.A., Pérez-Folgado, M., VÁzquez, A. \& Utrilla, R. 2005. Surface water dynamics and phytoplankton communities during deposition of cyclic late Messinian sapropel sequences in the western Mediterranean. Marine Micropaleontology 56, 50-79. DOI 10.1016/j.marmicro.2005.04.002

Francois, R., Honjo, S., Manganini, S.J. \& Ravizza, G.E. 1995. Biogenic barium fluxes to deep sea: implications for paleoproductivity reconstruction. Global Biogeochemical Cycles 9, 289-303. DOI 10.1029/95GB00021

Gallego-Torres, D., Martínez-Ruiz, F., Paytan, A., JiménezEspejo, F.J. \& Ortega-Huertas, M. 2007. Pliocene-Holocene evolution of depositional conditions in the eastern Mediterranean: Role of anoxia vs. productivity at 632 time of sapropel deposition. Palaeogeography, Palaeoclimatology, Palaeoecology 246, 424-439.

DOI 10.1016/j.palaeo.2006.10.008

Gallego-Torres, D., Martínez-Ruiz, F., Meyers, P.A., Paytan, A., Jiménez-EsPejo, F.J. \& Ortega-Huertas, M. 2010. Productivity patterns and N-fixation associated with PlioceneHolocene sapropels: paleoceanographic and paleoecological significance. Biogeosciences 8, 415-431.

DOI 10.5194/bg-8-415-2011

García-Hernández, M., López-Garrido, A.C., MartínAlgarra, A., Molina, J.M., Ruiz-Ortiz, P.A. \& Vera, J.A. 1989. Las discontinuidades mayores del Jurásico de las Zonas Externas de las Cordilleras Béticas: Análisis e interpretación de los ciclos sedimentarios. Cuadernos de Geología Ibérica $13,35-52$.

García-Hernández, M., López-Garrido, A.C., Rivas, P., SAnZ de Galdeano, C. \& Vera, J.A. 1980. Mesozoic paleogeographic evolution of the External Zones of the Betic Cordillera. Geologie en Mijnbouw 59, 155-168.

García-Joral, F., GómEZ, J.J. \& Goy, A. 2011. Mass extinction and recovery of the early Toarcian (early Jurassic) brachiopods linked to climate change in Northern and Central Spain. Palaeogeography, Palaeoclimatology, Palaeoecology 302, 367-380. DOI 10.1016/j.palaeo.2011.01.023

GhadeEr, S.G. \& MacquaKer, J.H.S. 2011. Sediment transport processes in an ancient mud-dominated succession: a comparison of processes operating in marine offshore settings and anoxic basinal environments. Journal of the Geological Society 168, 1121-1132. DOI 10.1144/0016-76492010-016

GómEZ, J.J. \& ARIAS, C. 2010. Rapid warming and ostracods mass extinction at the Lower Toarcian (Jurassic) of central Spain. Marine Micropaleontology 74, 119-135.

DOI 10.1016/j.marmicro.2010.02.001

GómEz, J.J. \& GoY, A. 2011. Warming-driven mass extinction in the Early Toarcian (Early Jurassic) of northen and central Spain. Correlation with other time-equivalent European sections. Palaeogeography, Palaeoclimatology, Palaeoecology 306, 176-195. DOI 10.1016/j.palaeo.2011.04.018

Gupta, L.P. \& Kawahata, H. 2006. Downcore diagenetic changes in organic matter and implications for paleoproductivity estimates. Global and Planetary Change 53, 122-136. DOI 10.1016/j.gloplacha.2006.01.008

Hallam, A. 1986. The Pliensbachian and Tithonian extinction events. Nature 319, 765-768. DOI 10.1038/319765a0

Hallam, A. 1987. Radiations and extinctions in relation to envi- 
ronmental change in the marine Lower Jurassic of northwest Europe. Paleobiology 13, 152-168.

Hallam, A. 1996. Major Bio-Events in the Triassic and Jurassic, 265-283. In Walliser, O.H. (ed.) Global Events and Event Stratigraphy. Springer, Berlin.

Haq, B.U., Hardenbol, J. \& Vail, P.R. 1987. Chronology of fluctuating sea level since the Triassic. Science 235, 1156-1167. DOI 10.1126/science.235.4793.1156

Hermoso, M., Le Callonnec, L., Minoletti, F., Renard, M. \& Hesselbo, S.P. 2009a. Expression of the Early Toarcian negative carbon-isotope excursion in separated carbonate microfractions (Jurassic, Paris Basin). Earth and Planetary Science Letters 277, 194-203. DOI 10.1016/j.epsl.2008.10.013

Hermoso, M., Minoletti, F., Le Callonnec, L., Jenkyns, H.C., Hesselbo, S.P., Rickaby, R.E.M., Renard, M., De Rafaeli, M. \& Emmanuel, L. 2009b. Global and local forcing of Early Toarcian seawater chemistry: A comparative study of different paleoceanographic settings (Paris and Lusitanian basins). Paleoceanography 24, PA4208. DOI 10.1029/2009PA001764

Hesselbo, S.P., Gröcke, D.R., Jenkyns, H.C., BJerrum, C.J., Farrimond, P., Morgans Bell, H.S. \& Green, O.R. 2000. Massive dissociations of gas hydrate during a Jurassic oceanic anoxic event. Nature 406, 392-395. DOI 10.1038/35019044

Hesselbo, S.P., Jenkyns, H.C., Duarte, L.V. \& Oliveira, L.C.V. 2007. Carbon isotope record of the Early Jurassic (Toarcian) Oceanic Anoxic Event from fossil word and marine carbonate (Lusitanian Basin, Portugal). Earth and Planetary Science Letters 253, 455-470. DOI 10.1016/j.epsl.2006.11.009

Jenkyns, H.C. 1985. The Early Toarcian and CenomanianTuronian anoxic events in Europe: Comparisons and contrasts. Geologische Rundschau 74, 505-518. DOI 10.1007/BF01821208

Jenkyns, H.C. 1988. The early Toarcian (Jurassic) Oceanic Anoxic Event: Stratigraphic, sedimentary, and geochemical evidence. American Journal of Science 288, 101-151. DOI 10.2475/ajs.288.2.101

Jenkyns, H.C. \& Clayton, C.K. 1997. Lower Jurassic epicontinental carbonates and mudstones from England and Wales: chemostratigraphic signals and the early Toarcian anoxic event. Sedimentology 44, 687-706. DOI 10.1046/j.1365-3091.1997.d01-43.x

Jenkyns, H.C., Jones, C.E., Gröcke, D.R., Hesselbo, S.P. \& PARKINSON, D.N. 2002. Chemostratigraphy of the Jurassic System: applications, limitations and implications for palaeoceanography. Journal of the Geological Society, London 159, 351-378. DOI 10.1144/0016-764901-130

Jiménez, A.P., JimÉnEZ de Cisneros, C., Rivas, P. \& Vera, J.A. 1996. The early Toarcian anoxic event in the westernmost Tethys (Subbetic): Paleogeographic and paleobiogeographic significance. Journal of Geology 104, 399-416. DOI $10.1086 / 629836$

JiMÉNEZ, A.P. \& RIVAS, P. 2007. El OAE toarciense en la secuencia de la Fuente de la Vidriera, Zona Subbética, región de Caravaca (Murcia), 3-16. In Aguirre, J., Company, M. \& Rodríguez-Tovar, F.J. (eds) XXIII Jornadas de la Sociedad Española de Paleontología, Caravaca, Field Trip Guidebook. Universidad de Granada, Granada.

JimÉnez-Espejo, F.J., Martínez-Ruiz, F., SAKamoto, T., IjJima,
K., Gallego-Torres, D. \& Harada, N. 2007. Paleoenvironmental changes in western Mediterranean since the last glacial maximum: high resolution multiproxy record from the Algero-Balearic basin. Palaeogeography, Palaeoclimatology, Palaeoecology 246, 292-306.

DOI 10.1016/j.palaeo.2006.10.005

Jones, B.A. \& MANning, D.A.C. 1994. Comparison of geochemical indices used for the interpretation of paleoredox conditions in ancient mudstones. Chemical Geology 111, 111-129.

DOI 10.1016/0009-2541(94)90085-X

Kemp, D.B., Coe, A.L., Cohen, A.S. \& Schwark, L. 2005. Astronomical pacing of methane release in the Early Jurassic period. Nature 437, 396-399. DOI 10.1038/nature04037

LAtimer, J.C. \& FilipPelli, G.M. 2001. Terrigenous input and paleoproductivity in the Southern Ocean. Paleoceanography 16, 627-643. DOI 10.1029/2000PA000586

LitTler, K., Hesselbo, S.P. \& Jenkyns, H.C. 2010. A carbon-isotope perturbation at the Pliensbachian-Toarcian boundary: evidence from the Lias Group, NE England. Geological Magazine 147, 181-192. DOI 10.1017/S0016756809990458

Mailliot, S., Mattioli, E., Guex, J. \& Pittet, B. 2006. The Early Toarcian anoxia, a synchronous event in the Western Tethys? An approach by quantitative biochronology (Unitary Associations), applied on calcareous nannofossils. Palaeogeography, Palaeoclimatology, Palaeoecology 240, 562-586.

DOI 10.1016/j.palaeo.2006.02.016

Martínez-Ruiz, F., Kastner, M., Paytan, A., Ortega-Huertas, M. \& BernASCONI, S.M. 2000. Geochemical evidence for enhanced productivity during S1 sapropel deposition in the eastern Mediterranean. Paleoceanography 15, 200-209. DOI 10.1029/1999PA000419

Martínez-Ruiz, F., Paytan, A., Kastner, M., GonzálezDonoso, J.M., Linares, D., Bernasconi, S.M. \& JimÉnezESPEJO, F.J. 2003. A comparative study of the geochemical and mineralogical characteristics of the S1 sapropel in the western and eastern Mediterranean. Palaeogeography, Palaeoclimatology, Palaeoecology 190, 23-37. DOI 10.1016/S0031-0182(02)00597-7

McArthur, J.M. 2007. Common on "Carbon-isotope record of the Early Jurassic (Toarcian) Oceanic Anoxic Event from fossil wood and marine carbonate (Lusitanian Basin, Portugal)" by Hesselbo, S., Jenkyns, H.C., Duarte, L.V. and Oliveira, L.C.V. Earth and Planetary Science Letters 259, 634-639. DOI 10.1016/j.eps1.2007.04.055

McArthur, J.M., Algeo, T.J., van De Schootbrugge, B., Li, Q. \& Howarth, R.J. 2008. Basinal restriction, black shales, Re-Os dating, and the Early Toarcian (Jurassic) oceanic anoxic event. Paleoceanography 23, PA4217. DOI 10.1029/2008PA001607

McArthur, J.M., Donovan, D.T., Thirvall, M.F., Fouke, B.W. \& MAtTeY, D. 2000. Strontium isotope of the Early Toarcian (Jurassic) oceanic anoxic event, the duration of ammonite biozones and belemnite palaeotemperatures. Earth and Planetary Science Letters 179, 269-285.

DOI 10.1016/S0012-821X(00)00111-4

McElwain, J.C., Wade-Murphy, J. \& Hesselbo, S.P. 2005. Changes in carbon dioxide during an anoxic event linked to intrusion of Gondwana coals. Nature 435, 479-482. DOI 10.1038/nature03618 
Metodiev, L.S., Savov, I.P., Gröcke, D.R., Wignall, P.B., Newton, R.J., Andreeva, P.V. \& Koleva-Rekalova, E.K. 2012. Upper Pliensbachian - Toarcian (Jurassic) palaeoenvironmental perturbations in a temporal and regional context: an externded ${ }^{87} \mathrm{Sr} /{ }^{86} \mathrm{Sr}, \delta^{13} \mathrm{C}$ and $\delta^{18} \mathrm{O}$ belemnite isotope study from Bulgaria. Solid Earth Discuss 4, 315-361.

DOI 10.5194/sed-4-315-2012

NAGaO, S. \& NAKAShima, S. 1992. Possible complexation of uranium with dissolved humic substances in pore water of marine sediments. Science of the Total Environment 118, 439-447. DOI 10.1016/0048-9697(92)90109-6

NieBuHR, B. 2005. Geochemistry and time-series analyses of orbitally forced Upper Cretaceous marl-limestone rhythmites (Lehrte West Syncline, northern Germany). Geological Magazine 142, 31-55. DOI 10.1017/S0016756804009999

Paytan, A., Kastner, M. \& Chávez, F.P. 1996. Glacial to interglacial fluctuations in productivity in the equatorial Pacific as indicated by marine barite. Science 274, 1355-1357.

DOI 10.1126/science.274.5291.1355

Plewa, K., Meggers, H. \& Kasten, S. 2006. Barium in sediments off northwest Africa: A tracer for palaeoproductivity or meltwater events? Paleoceanography 21, PA2015. DOI 10.1029/2005PA001136

Powell, W.G., Johston, P.A. \& Collom, C.J. 2003. Geochemical evidence for oxygenated bottom waters during deposition of fossiliferous strata of the Burgess Shale Formation. Palaeogeography, Palaeoclimatology, Palaeoecology 201, 249-268. DOI 10.1016/S0031-0182(03)00612-6

Pye, K. 1987. Aeolian Dust and Dust Deposits. 334 pp. Academic Press, San Diego.

Reolid, M. \& Martínez-Ruiz, F. 2012. Comparison of benthic foraminifera and geochemical proxies in shelf deposits from the Upper Jurassic of the Prebetic (southern Spain). Journal of Iberian Geology 38, 449- 465.

Reolid, M., Rodríguez-Tovar, F.J., Marok, A. \& Sebane, A. 2012a. The Toarcian Oceanic Anoxic Event in the Western Saharan Atlas, Algeria (North African Paleomargin): role of anoxia and productivity. GSA Bulletin 124, 1646-1664. DOI 10.1130/B30585.1

Reolid, M., Rodríguez-Tovar, F.J. \& Nagy, J. 2012b. Ecological replacement of Valanginian agglutinated foraminifera during a maximum flooding event in the Boreal realm (Spitsbergen). Cretaceous Research 33, 196-204.

DOI 10.1016/j.cretres.2011.10.003

Rey, J. \& Delgado, A. 2002. Carbon and oxygen isotopes: A tool for Jurassic and early Cretaceous pelagic correlation (southern Spain). Geological Journal 37, 337-345. DOI 10.1002/gj.919

Robertson, A.K. \& FilipPelli, G.M. 2008. Paleoproductivity variations in the eastern equatorial Pacific over glacial timescales. American Geophysical Union Fall Meeting 2008, Abstract PP33C-1576.

Rodríguez-Tovar, F.J. \& Uchman, A. 2010. Ichnofabric evidence for the lack of bottom anoxia during the Lower Toarcian Oceanic Anoxic Event (T-OAE) in the Fuente de la Vidriera section, Betic Cordillera, Spain. Palaios 25, 576-587. DOI 10.2110/palo.2009.p09-153r

RöHl, H.J., Schmid-Röhl, A., Oschmann, W., Frimmel, A. \& SCWARK, L. 2001. The Posidonian Shale (Lower Toarcian) of SW-Germany: an oxygen-depleted ecosystem controlled by sea level and paleoclimate. Palaeogeography, Palaeoclimatology, Palaeoecology 165, 27-52.

DOI 10.1016/S0031-0182(00)00152-8

Ruban, D.A. \& TyszKa, J. 2005. Diversity dynamics and mass extinctions of the Early-Middle Jurassic foraminifers: A record from the Northwestern Caucasus. Palaeogeography, Palaeoclimatology, Palaeoecology 222, 329-343.

DOI 10.1016/j.palaeo.2005.03.021

Sabatino, N., Neri, R., Bellanca, A., Jenkyns, H.C., Baudin, F., Parisi, G. \& MASETti, D. 2009. Carbon-isotope records of the Early Jurassic (Toarcian) oceanic anoxic event from the Valdorbia (Umbria-Marche Apennines) and Monte Mangart (Julian Alps) sections: palaeoceanographic and stratigraphic implications. Sedimentology 56, 1307-1328.

DOI 10.1111/j.1365-3091.2008.01035.x

SÆlen, G., Tyson, R.V., Telnæs, N. \& Talbot, M.R. 2000. Contrasting watermass conditions during deposition of the Whitby Mudstone (Lower Jurassic) and Kimmeridge Clay (Upper Jurassic) formations, UK. Palaeogeography, Palaeoclimatology, Palaeoecology 163, 163-196.

DOI 10.1016/S0031-0182(00)00150-4

Sen, A.K., FilipPelli, G.M. \& Flores, J.A. 2008. An application of wavelet analysis to palaeoproductivity records from the Southern Ocean. Computers \& Geosciences 35, 1445-1450. DOI 10.1016/j.cageo.2008.10.003

Siebert, C., Nagler, T.F., von Blanckenburg, F. \& Kramers, J.D. 2003. Molybdenum isotope records as a potential new proxy for paleoceanography. Earth and Planetary Science Letters 211, 159-171. DOI 10.1016/S0012-821X(03)00189-4

Su, W., Wang, Y., Cramer, B.D., Munnecke, A., Li, Z. \& Fu, L. 2008. Preliminary estimation of palaeoproductivity via TOC and habitat types: which method is more reliable? A case study on the Ordovician/Silurian transitional black shales of the Upper Yangtze Platform, South China. Journal of China University of Geosciences 19, 534-548.

DOI 10.1016/S1002-0705(08)60059-X

Suan, G., Pittet, B., Bour, I., Mattioli, E., Duarte, L.V. \& MaIlliot, S. 2008. Duration of the Early Toarcian carbon isotope excursion deduced from spectral analysis: Consequence for its possible causes. Earth and Planetary Science Letters 267, 666-679. DOI 10.1016/j.eps1.2007.12.017

Sun, Y.B., Wu, F., Clemens, S.C. \& Oppo, D.W. 2008. Processes controlling the geochemical composition of the South China Sea sediments during the last climatic cycle. Chemical Geology 257, 234-249. DOI 10.1016/j.chemgeo.2008.10.002

Thomson, J., Higgs, N.C., Wilson, T.R.S., Croudace, I.W., de LANGe, G.J. \& VAn SANTwoort, P.J.M. 1995. Redistribution and geochemical behaviour of redox-sensitive elements around S1, the most recent eastern Mediterranean sapropel. Geochimica et Cosmochimica Acta 59, 3487-3501. DOI 10.1016/0016-7037(95)00232-O

Thomson, J., Mercone, D., De Lange, G.J. \& Van Santvoort, P.J.M. 1999. Review of recent advances in the interpretation of eastern Mediterranean sapropel S1 from geochemical evidence. Marine Geology 153, 77-89. DOI 10.1016/S0025-3227(98)00089-9

Trabucho-Alexandre, J., Dirkx, R., Veld, H., Klaver, G. \& DE Boer, P.L. 2012. Toarcian black shales in the Dutch Central Graben: Record of energetic, variable depositional conditions 
during an Oceanic Anoxic Event. Journal of Sedimentary Research 82, 104-120. DOI 10.2110/jsr.2012.5

Tribovillard, N., Algeo, T., Lyons, T. \& Riboulleau, A. 2006. Trace metals as palaeoredox and palaeoproductivity proxies: an update. Chemical Geology 232, 12-32. DOI 10.1016/j.chemgeo.2006.02.012

Turgeon, S. \& Brumsack, H.J. 2006. Anoxic vs dysoxic events reflected in sediment geochemistry during the CenomanianTuronian Boundary Event (Cretaceous) in the Umbria-Marche basin of central Italy. Chemical Geology 234, 321-339. DOI 10.1016/j.chemgeo.2006.05.008

TyszKA, J., JACH, R. \& BUBíK, M. 2010. A new vent-related foraminifer from the lower Toarcian black claystone of the Tatra Mountains, Poland. Acta Palaeontologica Polonica 55, 333-342. DOI 10.4202/app.2009.0082

van de Schootbrugge, B., McArthur, J.M., Bailey, T.R., Rosenthal, Y., Wright, J.D. \& Miller, K.G. 2005. Toarcian oceanic anoxic event: An assessment of global causes using belemnite isotope records. Paleoceanography 20, PA3008. DOI 10.1029/2004PA001102

Van Os, B.J.H., Lourens, L.J., Hilgen, F.J., DE LANGe, G.J. \&
Beaufort, L. 1994. The formation of Pliocene sapropels and carbonate cycles in the Mediterranean: Diagenesis, dilution, and productivity. Paleoceanography 9, 601-617. DOI 10.1029/94PA00597

VerA, J.A. 2004. Geología de España. 884 pp. Sociedad Geológica de España - IGME, Madrid.

Wignall, P.B. \& Myers, K.J. 1988. Interpreting the benthic oxygen levels in mudrocks: a new approach. Geology 16, 452-455.

DOI 10.1130/0091-7613(1988)016<0452:IBOLIM>2.3.CO;2

Wignall, P.B., Newton, R.J. \& Little, C.T.S. 2005. The timing of paleoenvironmental change and cause-and-effect relationships during the Early Jurassic mass extinction in Europe. American Journal of Science 305, 1014-1032.

DOI 10.2475/ajs.305.10.1014

Yilmaz, I.O., Altiner, D., Tekin, U.K., Tuysuz, O., Ocakoglu, F. \& ACIKAlIN, S. 2010. Cenomanian-Turonian Oceanic Anoxic Event (OAE2) in the Sakarya zone, northwestern Turkey: sedimentological, cyclostratigraphic, and geochemical records. Cretaceous Research 31, 207-226.

DOI 10.1016/j.cretres.2009.10.005 